\title{
Integrated tephrostratigraphy and stable isotope stratigraphy in the Japan Sea and East China Sea using IODP Sites U1426, U1427, and U1429, Expedition 346 Asian Monsoon
}

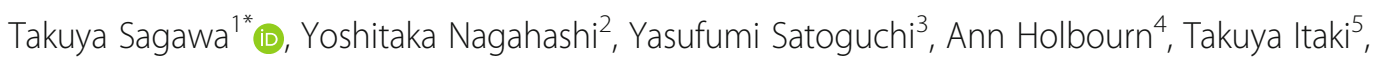
Stephen J. Gallagher ${ }^{6}$, Mariem Saavedra-Pellitero ${ }^{7}$, Ken Ikehara ${ }^{5}$, Tomohisa Irino ${ }^{8}$ and Ryuji Tada ${ }^{9}$

\begin{abstract}
Integrated Ocean Drilling Program Expedition 346 "Asian Monsoon" obtained sediment successions at seven sites in the Japan Sea (Sites U1422-U1427 and U1430) and at two closely located sites in the northern East China Sea (Sites U1428 and U1429). The Quaternary sediments of the Japan Sea are characterized by centimeter- to decimeter-scale dark-light alternations at all sites deeper than $500 \mathrm{~m}$ water depth. The sedimentary records from these sites allow an investigation of the regional environmental response to global climate change, including changes in the Asian Monsoon and eustatic sea level. However, the discontinuous occurrence of calcareous microfossils in the deep-sea sediments and their distinct isotope signature that deviates from standard marine $\delta^{18} \mathrm{O}$ records do not permit the development of a detailed stable isotope stratigraphy for Japan Sea sediments. Here, we present the tephrostratigraphy for the two southernmost sites drilled in the Japan Sea (Sites U1426 and U1427) and for one site drilled in the East China Sea (Site U1429) along with the benthic $\delta^{18} \mathrm{O}$ isotope stratigraphy for the shallower Site U1427 and the East China Sea Site U1429. Eighteen tephra layers can be correlated between sites using the majorelement composition and morphology of volcanic glass shards, and the compositions of grains and heavy minerals. Tephra correlations show that negative $\delta^{18} \mathrm{O}$ peaks in the Japan Sea correspond to positive glacial maxima peaks in the East China Sea. Using this integrated stratigraphic approach, we establish an orbital-scale age model at Site U1427 for the past 1.1 Myr. The correlation of tephra layers between the shallower Site U1427 (330 m below sea level: mbsl) and the deeper Site U1426 (903 mbsl) in the southern Japan Sea provides the opportunity for further age constraints. Our results show that alternations in sediment color at Sites U1426 and U1427 can be correlated for the past 1.1 Myr with minor exceptions. Thus, the stable isotope stratigraphy established at the shallower Site U1427 can be correlated to Site U1426, and in turn to all sites drilled during Expedition 346, based on correlations of dark-light layering.
\end{abstract}

Keywords: Japan Sea, East China Sea, Tephrostratigraphy, Stable isotope stratigraphy, Integrated Ocean Drilling Program, Expedition 346, Inter-site correlation

\footnotetext{
* Correspondence: tsagawa@staff.kanazawa-u.ac.jp

'Institute of Science and Engineering, Kanazawa University, Kakuma-machi,

Kanazawa, Ishikawa 920-1192, Japan

Full list of author information is available at the end of the article
} 


\section{Introduction}

Integrated Ocean Drilling Program (IODP) Expedition 346 "Asian Monsoon" drilled seven sites in the Japan Sea (JS) and two closely located sites in the northern East China Sea (ECS) (Fig. 1). The main scientific goal of this expedition was to unravel the evolution and variability of the East Asian monsoon over multiple timescales. The JS drilling sites spanned both latitudinal and depth transects in order to explore linkages between atmospheric and oceanic processes, along the edge of the Eurasian continent, the Korean Peninsula, and the Japanese islands, and to investigate regional responses to far-field forcing. However, detailed correlation of the suite of cores obtained during Expedition 346 is a pre-requisite for any regional paleoclimatic and paleoceanographic reconstructions.

The late Quaternary deep-sea sediment in the JS is characterized by centimeter- to decimeter-scale alternations of dark and light layers (Tada et al. 1992 1999; Nakajima et al. 1996), with the darker sediment occasionally showing fine laminations. The alternation of color was caused by changes in deep-water oxygenation in sediments recovered from depths $>500 \mathrm{~m}$ below sea level (mbsl) (Ikehara et al. 1994). Dark-light color alternations are present at six of the seven sites drilled during Expedition 346 (Sites U1422-U1426 and U1430), and they occupy water depths of 990-3430 mbsl, whereas the succession at Site U1427 on the outer margin of a marginal terrace ( $330 \mathrm{mbsl})$ shows gradual and subtle color changes (Fig. 1). Previous studies have demonstrated that the darklight layers in sediments from deeper sites can be correlated across the JS (e.g., Tada et al. 1992; Nakajima et al. 1996). This is also the case for the six deeper sites of Expedition 346 , which are readily correlated over the past $1.5 \mathrm{Myr}$ (Tada et al. 2018). Due to its tectonic setting, the JS and

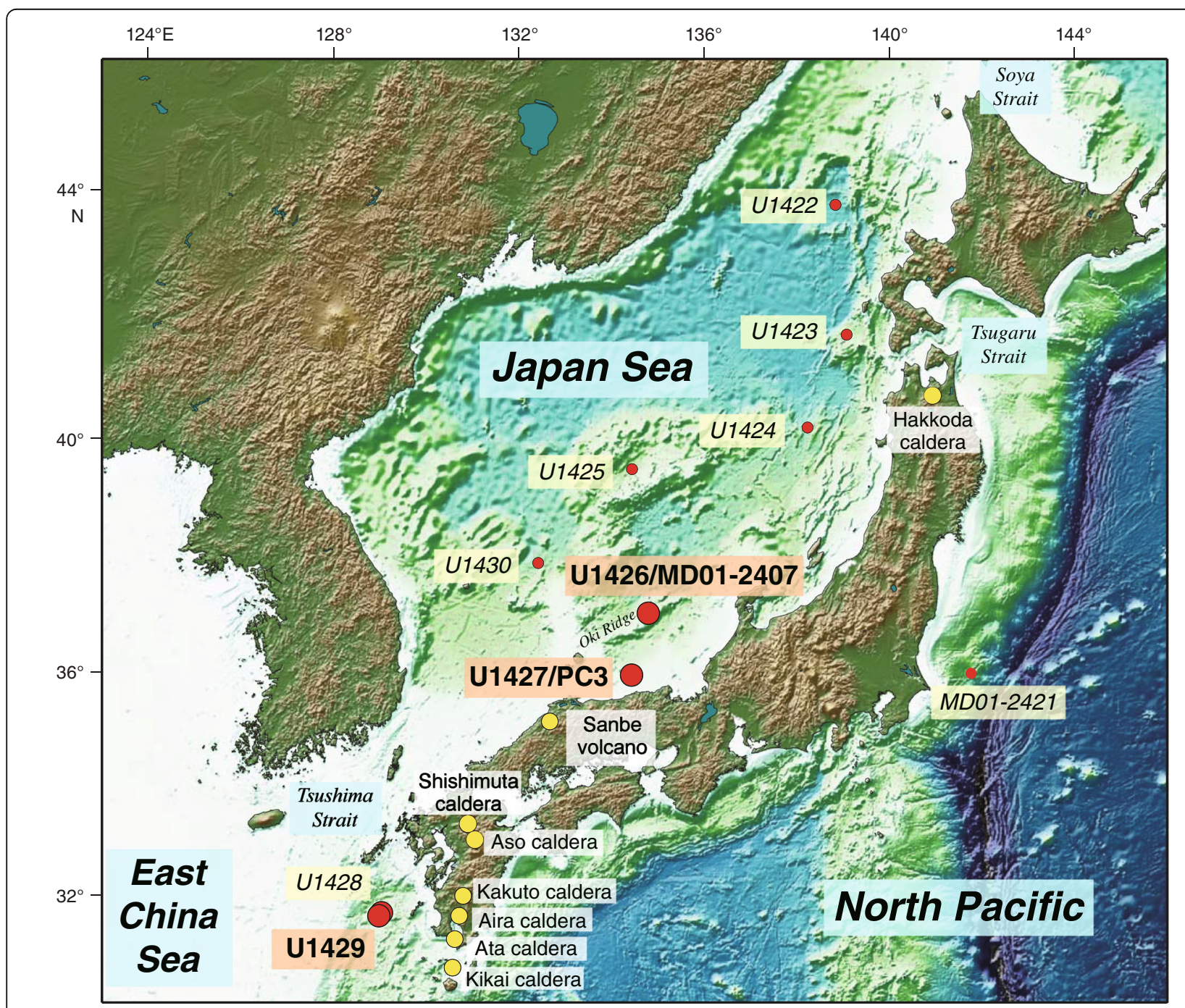

Fig. 1 Locations of sites drilled during IODP Expedition 346 in the Japan Sea and East China Sea. The source volcanoes of some of the regional tephra layers are shown 
northern ECS sediments contain a large number of tephra layers that were erupted from volcanoes on the Japanese islands and the Korean Peninsula (Ikehara 2015). Tephra deposition is geologically synchronous; therefore, tephra layers provide an excellent way to precisely correlate sediment successions in the JS and the ECS.

The Pliocene and Pleistocene tephrostratigraphy and tephrochronology of the Japanese islands were summarized by Machida (1999), Tamura and Yamazaki (2010), and Satoguchi and Nagahashi (2012). Major- and traceelement compositions of volcanic glass shards of the more regionally widespread tephra layers were investigated by Nagahashi et al. (2004, 2007, 2015). These element compositions of tephra layers have been used to identify and correlate the layers (e.g., Nagahashi et al. 2004). Tephra layers in JS sediments were originally described by Pouclet and Scott (1992), who summarized their temporal distribution in the sediments of ODP Leg $127 / 128$. These tephra layers were subsequently investigated to understand the nature of volcanic activity (Nakagawa et al. 1994) in order to identify the sources and to establish relationships with oxygen isotope stratigraphy for the past 400 kyr (Shirai et al. 1997). The stratigraphy and petrography of Upper Pleistocene marine tephras from the JS and the North Pacific Ocean were summarized by Ikehara (2015) and Aoki (2008), respectively. However, the long-term tephrostratigraphy of JS sediments, its correlation with known widespread tephra layers, and the tephrochronology for the past several million years have not been established to date. If the tephrostratigraphy of JS sediments is known, comparison of environmental changes between the Japanese islands and the Japan Sea will be possible. Here, we provide correlations between tephra layers that are interbedded in sediment successions at Sites U1426, U1427, and U1429 with regionally occurring tephras in order to determine isochronous horizons for these sites.

The generation of orbital-scale age models for the JS sediments is complicated by the sporadic occurrence and variable preservation of calcareous microfossils, which hinders the construction of a detailed oxygen isotope stratigraphy. Furthermore, the JS carbonate compensation depth (CCD) has varied from < 1000 to > $3000 \mathrm{~m}$ over the past $30 \mathrm{kyr}$ (Oba et al. 1991), and the JS oxygen isotope signal is different from that of the open ocean, as it is a semi-enclosed environment (e.g., Oba et al. 1991; Kido et al. 2007; Yokoyama et al. 2007). The IS is connected to the North Pacific Ocean and adjacent marginal seas (ECS and Okhotsk Sea) only by shallow and narrow straits (Fig. 1). Even the sill depths of the deepest connections to the open ocean, the Tsushima and Tsugaru Straits, are only $\sim 130 \mathrm{~m}$, while the sill depths in the Soya Strait and the Mamiya Strait are $\sim 55$ and $\sim 15 \mathrm{~m}$, respectively. Therefore, glacial- interglacial sea-level change has had a marked influence on seawater exchange through the straits. For example, during the last glacial maximum (LGM), the JS was almost isolated from the surrounding seas, resulting in planktonic $\delta^{18} \mathrm{O}$ minima that are interpreted as a signal of low-salinity surface water (Oba et al. 1991).

The shallow Site U1427 is an important site for Expedition 346 site correlation for two main reasons. First, as it is in the southern part of the JS, the sediment succession at Site U1427 contains tephra layers that are also present at the ECS sites. These tephra layers can be used to constrain the JS $\delta^{18} \mathrm{O}$ stratigraphy and to correlate the $\delta^{18} \mathrm{O}$ stratigraphy of the JS to the ECS, the latter with an open-ocean $\delta^{18} \mathrm{O}$ signal. Second, the sediment at this site contains calcareous microfossils throughout the succession, except for two intervals (Tada et al. 2015a), thereby allowing high-resolution $\delta^{18} \mathrm{O}$ analyses. Once inter-site correlation between Site U1427 and the deeper JS sites is achieved, the U1427 $\delta^{18} \mathrm{O}$ stratigraphy can be projected to the deeper sites, where the preservation of foraminifera is poor.

\section{Objectives of this study}

This study aims to (1) establish a tephrostratigraphy for the past 1.1 Myr based on tephra layers interbedded in the sediment successions of Sites U1426, U1427, and U1429; (2) construct age models for Sites U1427 and U1429; and (3) correlate the sediment succession of the shallow JS Site U1427 with the deeper JS Site U1426. To achieve these objectives, we investigate the petrography and major-element chemistry of tephra layers within the sediment successions at these three sites, analyze benthic foraminiferal oxygen isotopes at Sites U1427 and U1429, and analyze radiolarian, planktonic foraminiferal, and calcareous nannofossil assemblages at Site U1427. By using tephras as the primary correlating horizons, we are also able to correlate sediment color variations at shallow- and deep-water sites in the JS.

\section{Geographical and oceanographical setting}

The JS and ECS are marginal seas located along the eastern margin of the Eurasian continent (Fig. 1). The JS is connected with the North Pacific Ocean, Okhotsk Sea, and East China Sea. Although the maximum water depth in the JS is $3700 \mathrm{~m}$, the straits connecting to adjacent seas are shallow $(<130 \mathrm{~m})$, meaning that intermediate and deep waters in the JS are separated from the adjacent seas. The only surface water flowing into the JS is the Tsushima Warm Current (TWC) flowing from the ECS through the Tsushima Strait. Since the TWC originates from the Kuroshio Current in the subtropical North Pacific Ocean and mixes with nutrient-rich coastal water derived from the Yangtze River in the ECS, 
this surface current supplies heat, salt, and nutrients to the JS.

During the LGM, the sill depths of the two deepest straits were $\sim 10 \mathrm{~m}$ (Matsui et al. 1998). Thus, surface water exchange through the straits was limited, and TWC inflow was restricted, resulting in reduced salt supply from the ECS. The surface water freshening is recorded in the planktonic foraminiferal $\delta^{18} \mathrm{O}$ data of deep-sea sediments across the JS (Oba et al. 1991). Therefore, the oxygen isotope stratigraphy in the JS is complicated by glacio-eustatic effects on surface salinity. Since carbonate $\delta^{18} \mathrm{O}$ values reflect both temperature and seawater $\delta^{18} \mathrm{O}$, the JS planktonic foraminifera $\delta^{18} \mathrm{O}$ values reflect two kinds of minima on a glacial-interglacial time scale: (1) during interglacial maxima (warm conditions) and (2) during glacial maxima (low seawater $\delta^{18} \mathrm{O}$; i.e., low salinity). Therefore, to correlate with marine isotope stages, one should interpret planktonic $\delta^{18} \mathrm{O}$ data along with temperature information derived from, for example, planktonic microfossil assemblages (Kido et al. 2007). In this study, we focus on the benthic foraminiferal $\delta^{18} \mathrm{O}$ record in the shallow Site U1427 (Fig. 1). The water depth of this site is $\sim 330 \mathrm{mbsl}$, well below the modern thermocline, which remains at $\sim 100-250 \mathrm{~m}$ water depth throughout the year (World Ocean Atlas 2013 (Locarnini et al. 2013)). Thus, the warm signal, attributed to intrusion of the TWC during interglacial maxima, is not expected to be recorded in the benthic $\delta^{18} \mathrm{O}$ values, thereby eliminating $\delta^{18} \mathrm{O}$ minima induced by warm temperatures during the interglacial maxima.

Glacio-eustatic sea-level change also influenced the ecological environment in the JS. Since the sea-level drop during glacial periods restricted the inflow of the TWC, assemblages of planktonic microfossils during glacial and interglacial periods differed markedly (Oba et al. 1991), and subtropical species were present only during interglacials. Therefore, combining records of benthic $\delta^{18} \mathrm{O}$ and TWC planktonic microfossil species at Site U1427 allows glacials to be distinguished from interglacials, which can be used to establish an orbital-scale age model.

\section{Methods/Experimental}

\section{Sediment cores}

Site U1426 is in the south-central part of the JS, near the top of the Oki Ridge $\left(37^{\circ} 2.00^{\prime} \mathrm{N}, 134^{\circ} 48.00^{\prime} \mathrm{E}, 903 \mathrm{mbsl}\right)$ (Fig. 1). The sediment succession of the upper $120 \mathrm{~m}$ is characterized by decimeter-scale color banding with alternations of dark and lighter brown layers (Fig. 2a). The organic-rich darker layers generally display a sharp base, whereas the upward transition from dark to light layers is gradational and commonly strongly bioturbated (Tada et al. 2015b). Some darker layers are thinly laminated. Calcareous microfossil preservation is relatively good in the upper part of the succession at this site compared with deeper sites, although foraminifera are poorly preserved or absent in some intervals (Tada et al. 2015b). Several tephra layers occur in the succession.

Site U1427 is located in the south-central part of the JS on the outer margin of the marginal terrace off Tottori $\left(35^{\circ} 57.92^{\prime} \mathrm{N}, 134^{\circ} 26.06^{\prime} \mathrm{E}, 330 \mathrm{mbsl}\right), \sim 110 \mathrm{~km}$ south of Site U1426 (Fig. 1). The sediment is dominated by heavily bioturbated and homogeneous clayey silt. Faint laminations are present in the intervals at 162177, 225-246, and 346-372 m (U1427_patched_CCSF-D _rev20170310, CCSF: core composite depth below seafloor, see below for explanation of the "patched" depthscale). Centimeter-thick tephra layers occur frequently throughout the succession. Owing to its proximity to Site U1426, it is likely that the same tephra layers are present at both sites. The sediment at this site differs from that of deeper JS sites, including Site U1426, as it lacks dark-light color banding. Instead, the sediment shows gradual meter-scale color changes accompanied by lithological changes (Fig. 2a). The sediment contains well-preserved foraminifera throughout, except for the two laminated intervals in the upper part of the core (Tada et al. 2015a). Sites U1427 and U1426 are close to the first and second branch of the TWC, respectively.

Site U1429 is in the southern part of the Danjo Basin in the northwestern part of the ECS $\left(31^{\circ} 37.04^{\prime} \mathrm{N}, 128^{\circ}\right.$ $\left.59.85^{\prime} \mathrm{E}, 732 \mathrm{mbsl}\right)$. The upper $\sim 180 \mathrm{~m}$ of the succession is characterized by calcareous-nannofossil-rich clay with diatoms and foraminifera (Tada et al. 2015c). The sediment is heavily bioturbated throughout and shows subtle meter-scale color variability (Fig. 2a). Tephra layers of various thickness, ranging from centimeter-scale to $>0.5 \mathrm{~m}$, are present throughout the succession.

The shipboard composite sections, so-called "splice sections," of Sites U1426 and U1427 (Tada et al. 2015a, 2015b) were revised post-cruise based on re-examination of close-up section photographs; the splice of Site U1429 is from Tada et al. (2015c). During this re-evaluation, a stratigraphical gap and repeated successions were found in the original shipboard splice (Irino et al. 2018). Detailed inter-hole correlation and revision of the shipboard splices for Sites U1426 and U1427 are presented by Irino et al. (2018). The depth-scale for the revised splice section is expressed as "patched_CCSF-D" in this study. The depthscale for Sites U1426 and U1427 used in this study are the latest versions, "U1426_patched_CCSF-D_rev20150519" and "U1427_patched_CCSF-D_rev20170310," respectively, unless noted otherwise.

\section{Shipboard measurements}

Sediment cores recovered during the expedition were analyzed using a Whole-Round Multisensor Logger (WRMSL; measuring $P$ wave velocity, density, and magnetic susceptibility), Natural Gamma Radiation Logger (NGRL), Section 


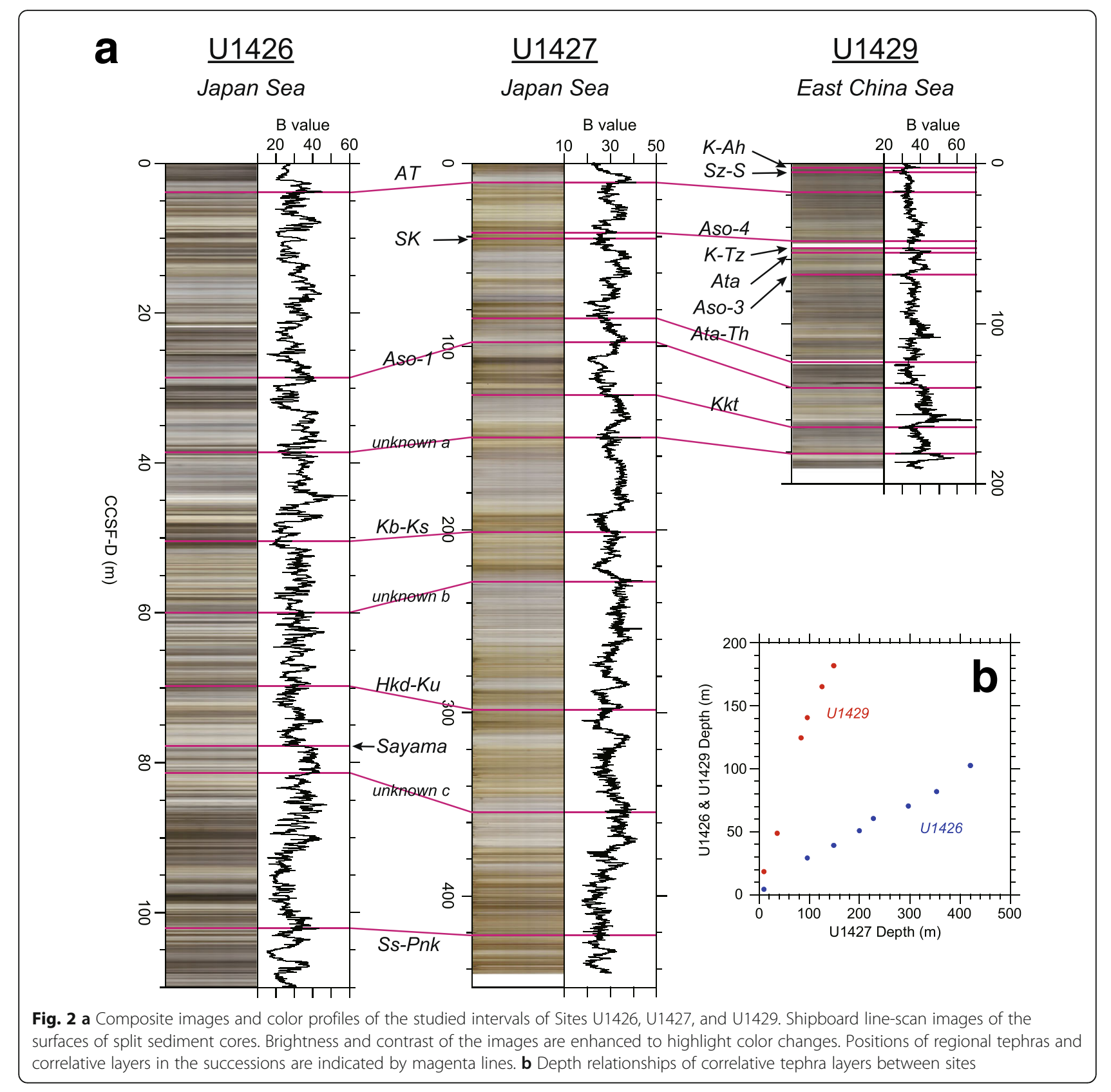

Half Imaging Logger (SHIL), and Section Half Multisensory Logger (SHMSL). For details of each method, please see the Methods chapter of the Proceedings volume (Tada et al. 2015d). The SHIL captures continuous high-resolution images of the archive half-surface. Images were collected shortly after core splitting and surface scraping to avoid color changes resulting from excessive sediment drying and oxidation of the surface. High-resolution color data (red, green, and blue) were acquired by digital color imaging. Reflectance of visible light and magnetic susceptibility (MS) were measured on the surfaces of sediment cores, which were covered with clear plastic wrap, on the SHMSL with an Ocean Optics USB4000 spectrophotometer and a
Bartington Instruments MS2E point sensor, respectively. These measurements were made at $1 \mathrm{~cm}$ spacing to provide high-resolution records. $\mathrm{L}^{*}, \mathrm{a}^{*}$, and $\mathrm{b}^{*}$ were calculated from the obtained reflectance spectra.

\section{Tephra}

We analyzed 56 samples from Site U1426, 56 samples from Site U1427, and 28 samples from Site U1429. Occurrences of tephra layers were recorded during shipboard visual core descriptions. Recognition of tephra layers was based on color, sedimentary structures, and components. The samples were ultrasonicated to remove clay contaminants and then separated into four 
grain-size fractions using 32,63 , and $250 \mu \mathrm{m}$ sieves. The major-element composition of volcanic glass shards was analyzed using scanning electron microscope-energy dispersive spectroscopy (SEM-EDS, Jeol JSM-6510LV +Oxford INCA x-Act EDS system) at Fukushima University, Japan. Synthetic and natural mineral standards were used primarily for quantitative calibrations. Compositions of eight major elements were further recalibrated by sub-standards, the compositions of which were determined by X-ray fluorescence (XRF) analysis (Nagahashi et al. 2003). In addition, the mineralogical composition, the morphology and relative compositions of volcanic glass shards, and the heavy mineral composition (specific gravity 2.8) were investigated for grains in the $63-250 \mu \mathrm{m}$ size fraction of samples collected from key correlative horizons. Images of glass morphology were obtained using a low-vacuum SEM (Hitachi Miniscope TM-1000).

\section{Oxygen isotope analyses}

Sediment samples for benthic foraminiferal isotope analysis at Site U1427 were washed using a $63 \mu \mathrm{m}$ sieve, and the residues were dried at $40{ }^{\circ} \mathrm{C}$ in an oven overnight. Uvigerina spp. and Cassidulina spp. were picked from the 250$355 \mu \mathrm{m}$ fraction of the dried residues. Picked foraminiferal shells were gently crushed using two glass plates under the microscope. The fragments were ultrasonicated several times with Milli-Q and methanol. The $\delta^{18} \mathrm{O}$ values of foraminifera in samples from Site U1427 were measured with a Thermo Finnigan MAT253 mass spectrometer connected to a Kiel III carbonate device at the Kochi Core Center, Japan. The isotope results were calibrated to the Vienna Pee Dee belemnite (VPDB) using the National Institute of Standards and Technology (NIST: Gaithersburg, Maryland) standard NBS 19 . The analytical precision was better than $\pm 0.06 \%$.

Sediment samples from Site U1429 were dried in an oven at $40{ }^{\circ} \mathrm{C}$, wet-sieved at $63 \mu \mathrm{m}$, and dried at $40{ }^{\circ} \mathrm{C}$. Between three and seven well-preserved tests of Uvigerina spp. were selected for analysis, except for a few samples in which Uvigerina was rare or absent, in which case Bulimina spp. or Cibicidoides spp. were selected. Tests were broken into large fragments, cleaned in alcohol in an ultrasonic bath, and then dried at $40{ }^{\circ} \mathrm{C}$. Replicate measurements of Site U1429 samples and core tops from several ocean basins (Holbourn et al. unpublished data) indicate no significant offset between the $\delta^{18} \mathrm{O}$ values of Uvigerina and Bulimina. The $\delta^{18} \mathrm{O}$ values of Cibicidoides were adjusted by adding $0.71 \%$ o to the original measurements to compensate for the offset between Uvigerina and Cibicidoides (Holbourn et al., unpublished core-top data). Measurements of benthic foraminiferal $\delta^{18} \mathrm{O}$ at Site U1429 were made using a Finnigan MAT251 mass spectrometer at the Leibniz Laboratory, Kiel
University, Germany. The instrument is coupled on-line to a Carbo-Kiel Device (type I). Samples were reacted by individual acid addition $\left(99 \% \mathrm{H}_{3} \mathrm{PO}_{4}\right.$ at $\left.73{ }^{\circ} \mathrm{C}\right)$. Standard external error was better than $\pm 0.08 \%$ o for $\delta^{18} \mathrm{O}$. Results were calibrated using the NIST carbonate isotope standards NBS 20,19 , and 18, and are reported on the VPDB scale.

\section{Microfossil analysis}

A total of 455 samples from Site U1427 were processed for radiolarian analysis (at $\sim 1.5 \mathrm{~m}$ intervals). Of these, 270 samples were from the upper $350 \mathrm{~m}$, which was the depth range targeted in this study. Detailed analytical methods and results for all samples analyzed are provided by Itaki et al. 2018. Based on previous studies of JS sediment cores, the radiolarian taxon, Tetrapyle octacantha group, occurred commonly during interglacial periods and only sporadically during glacial periods over the past 640 kyr (Itaki 2007; Itaki et al. 2007). In this study, we considered the following taxa as TWC indicators: the Tetrapyle octacantha group, Dictyocoryne spp., Didymocyrtis tetrathalamus, Euchitonia spp., and Spongaster tetras. These taxa are common in the subtropical regions today, and their distribution in the JS surface sediment is closely related to the inflow of the TWC (Motoyama et al. 2016). These TWC indicators are expressed as numbers of individuals per gram of dry sediment.

A total of 231 samples (at $\sim 1 \mathrm{~m}$ intervals) were processed for foraminiferal paleoenvironmental analyses. Sediment was washed with hydrogen peroxide over a $63 \mu \mathrm{m}$ wire mesh sieve. Dried residues were divided into fractions using a microsplitter, and a minimum of 100 individuals (typically $>200$ tests) were identified and counted in the > $150 \mu \mathrm{m}$ size fraction. Four subtropical planktonic foraminifera species (Globigerinoides ruber, Pulleniatina obliquiloculata, Globorotalia menardii, and Globorotalia tumida) are indicators of the TWC, along with the percentage of right-coiling Neogloboquadrina pachyderma (Neogloboquadrina incompta; sensu Darling et al. 2006) (Oba et al. 1991; Domitsu and Oda 2005; Gallagher et al. 2015). The \%TWC species and \%N. incompta are expressed as percentages of the total planktonic foraminifera assemblage.

Sixty samples were processed for coccolith analysis (at $\sim 3 \mathrm{~m}$ intervals). Sediment samples were freeze-dried and prepared following combined dilution and filtering (Andruleit 1996), which enabled estimates of the absolute numbers of coccoliths per gram of dry sediment. Between 61 and $129 \mathrm{mg}$ of dry bulk sediment was suspended in buffered water and treated ultrasonically for $\sim 30 \mathrm{~s}$. Samples were wet-split using a rotary sample divider, and $1 / 100$ of the original solution was filtered through polycarbonate filters $(0.45 \mu \mathrm{m}$ pore size $)$ with a vacuum pump. The filters were dried in an oven at $\sim 40^{\circ}$ $\mathrm{C}$ for at least $24 \mathrm{~h}$ and stored. A small part of each filter was cut out, fixed on an aluminum stub, and sputtered 

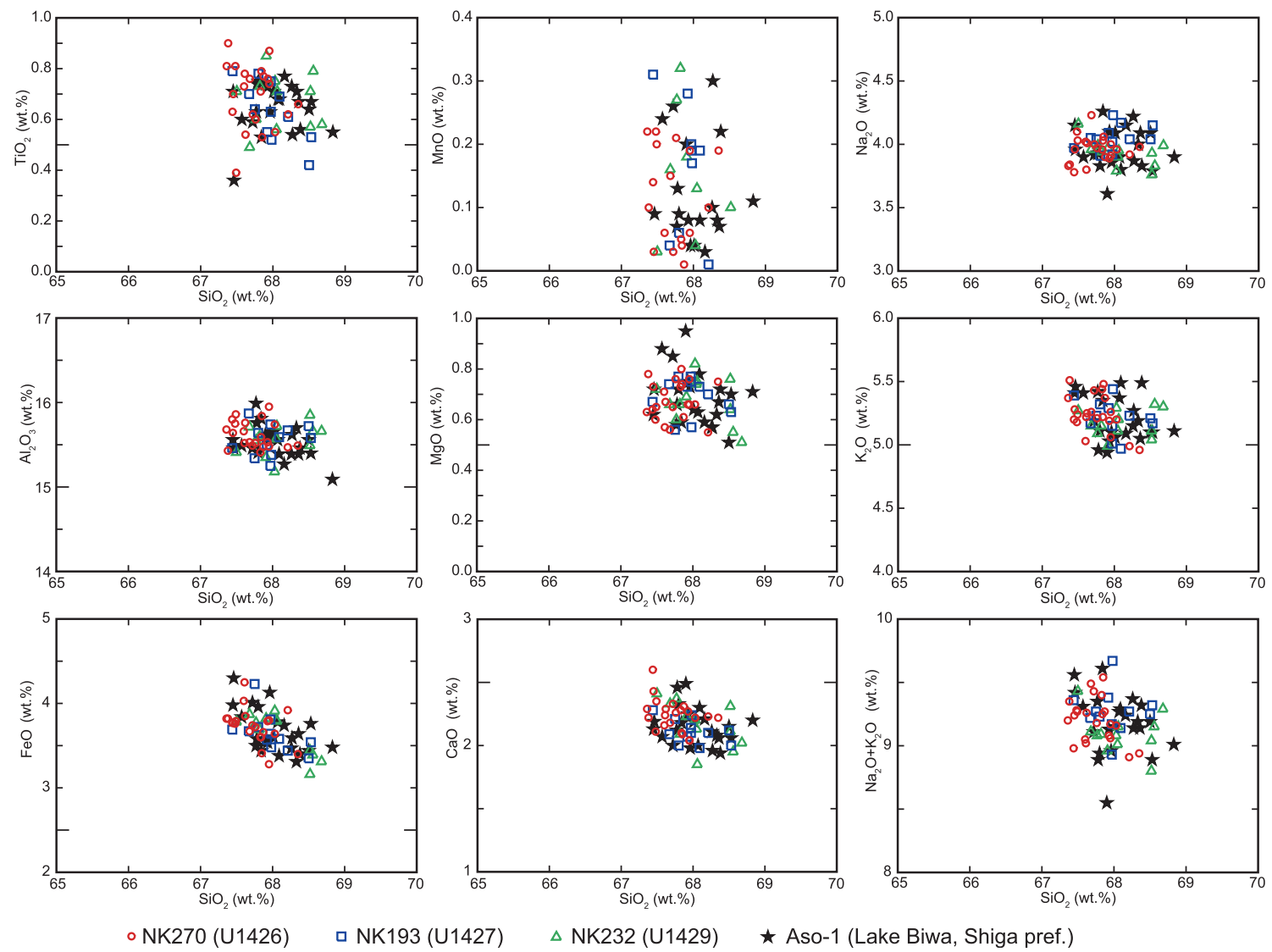

Fig. 3 Example of the Harker diagrams for correlative tephra samples from Sites U1426 (NK270), U1427 (NK193), U1429 (NK232), and the Aso-1 tephra in Lake Biwa sediment

with gold/palladium. Following a counting routine, a minimum of 400 coccoliths per sample were identified and classified under SEM at $\times 3000$ magnification. However, in a few cases, this minimum number was not reached. Identification of coccoliths followed Young et al. (2003) and the electronic guide Nannotax 3 (http://www.mikrotax.org/Nannotax3/). TWC indicators included the taxa Calcidiscus leptoporus, Gephyrocapsa oceanica, and Helicosphaera carteri (Muza 1992).

\section{Results and discussion}

\section{Correlation of tephra layers between sites and with} widespread tephra layers

The following screening procedure was applied for detecting correlative tephra between sites.

1) The concentrations of four major elements $\left(\mathrm{Al}_{2} \mathrm{O}_{3}\right.$, $\mathrm{FeO}, \mathrm{CaO}$, and $\mathrm{K}_{2} \mathrm{O}$ ) in volcanic glass shards were compared between sites, and samples with a consistent composition within two standard deviations $(2 \sigma)$ for each element were selected. We used these four oxides for the first screening as they are more accurately quantified and suitable for the discrimination of tephras than other elements.

2) All major-element compositions were plotted against $\mathrm{SiO}_{2}$ (i.e., Harker diagrams; Harker 1909), excluding data that differed between sites by more than $1 \sigma$.

3) If potentially correlative tephra layers passed the two previous screening steps but occurred in an inconsistent stratigraphic position in the successions between sites, they were eliminated from the list of correlative horizons.

4) Finally, the correlations were carefully assessed on the basis of lithofacies, mineralogical composition, the morphology and composition of volcanic glass shards, and heavy mineral composition.

Only tephras that passed all steps above were identified as correlative tephra layers. Furthermore, all tephra layers investigated in this study were examined to determine whether they are correlated to well-known widespread tephra layers of the Japanese islands, using the procedure noted above.

The well-known and widespread tephra Aso-1, which was deposited at $\sim 0.25 \mathrm{Ma}$, can be correlated between sites. The average major-element compositions of volcanic 
glass shards for NK270 at Site U1426, NK193 at Site U1427, and NK232 at Site U1429 show good agreement within $1 \sigma$ (Additional file 1: Table S1). The $\mathrm{SiO}_{2}$ contents of these samples are 67-69 wt\% and the relative compositions of elements plot in similar areas on Harker diagrams (Fig. 3). The mineralogical compositions are also consistent, with the samples comprising mainly volcanic glass shards and heavy minerals that are mainly orthopyroxene and clinopyroxene with minor hornblende and apatite (Additional file 2: Table S2). The morphologies of glass shards are platy and intermediate (platy and pumice) types (Fig. 4 and Additional file 2: Table S2). Based on the data above, NK270, NK193, and NK232 are correlated with each other. The major-element compositions of volcanic glass shards, grain composition, heavy minerals, and glass morphology of these tephra samples are similar to the BT61 tephra in the Takashima-oki sediment core from Lake Biwa (Yoshikawa and Inouchi 1993; Nagahashi et al. 2004) (Figs. 3 and 4; Additional files 1 and 2: Tables S1 and S2). The BT61 tephra is a co-ignimbrite ash (Sparks and Walker 1977) that was associated with the Aso-1 pyroclastic flow deposit erupted from the Aso caldera in the southern part of Kyushu Island (see Fig. 1 for the location of the Aso caldera). Furthermore, the stratigraphic positions of these samples are consistent with the stable isotope stratigraphy. Therefore, these three tephra layers correlate to the Aso-1 tephra.

There are 18 tephra layers that can be correlated between sites or to well-known widespread tephra layers of the past 1.1 Ma (Tables 1, S1, and S2). These are the Kikai-Akahoya (K-Ah), Sakurajima-Satsuma (Sz-S), Aira-Tanzawa (AT), Aso-4, Kikai-Tozurahara (K-Tz), Ata, Sanbe-Kisuki (SK), Aso-3, Ata-Torihama (Ata-Th), Aso-1, Kakuto (Kkt), Kobayashi-Kasamori (Kb-Ks), Hakkoda-Kokumoto (Hkd$\mathrm{Ku}$ ), and Shishimuta-Pink (Ss-Pink), from youngest to oldest (Table 1). All of the tephra layers, with the exception of three tephras (Sz-S, SK, and $\mathrm{Hkd}-\mathrm{Ku}$ ), are co-ignimbrite ash associated with large-scale pyroclastic flow eruptions on Kyushu island. Sz-S and SK are Plinian pumice-fall deposits from Sakurajima volcano in southern Kyushu and Sanbe volcano in the San-in area (Fig. 1). Hkd-Ku is a coignimbrite ash associated with a large-scale pyroclastic flow eruption of Hakkoda Caldera in northern Honshu Island. Figure $2 \mathrm{~b}$ shows the depth relationship of tephra layers at

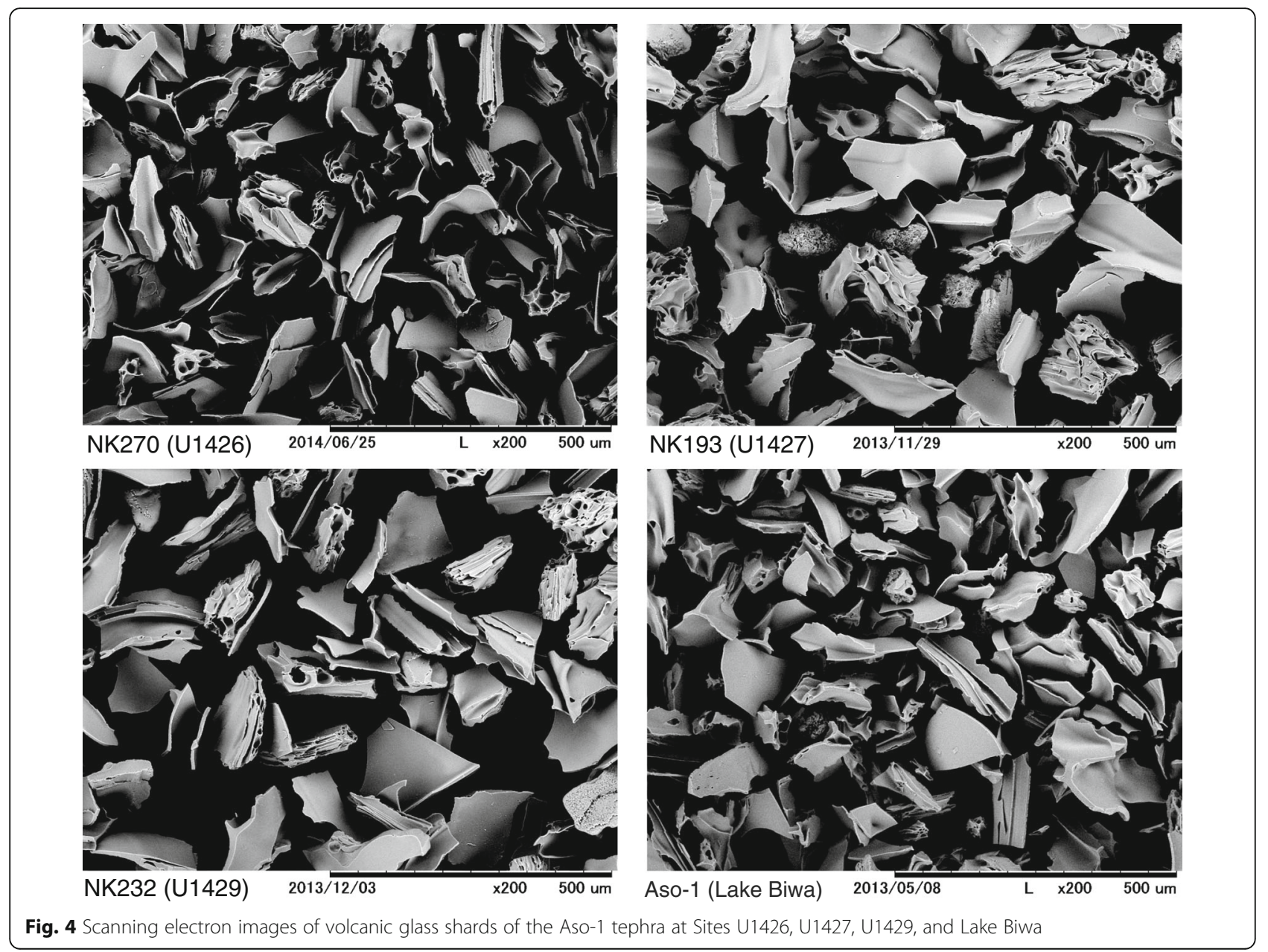


Table 1 Tephra layers identified at Sites U1426, U1427, and U1429

\begin{tabular}{|c|c|c|c|c|c|c|}
\hline \multicolumn{2}{|l|}{ U1429 } & \multicolumn{2}{|l|}{ U1427 } & \multicolumn{2}{|l|}{ U1426 } & \multirow{2}{*}{$\begin{array}{l}\text { Tephra } \\
\text { name }\end{array}$} \\
\hline Sample no. & Depth (m CCSF-D) & Sample no. & $\begin{array}{l}\text { Depth (m, Patched_ } \\
\text { CCSF-D_rev20170310) }\end{array}$ & Sample no. & $\begin{array}{l}\text { Depth (m, Patched_CCSF-D_ } \\
\text { rev20150519) }\end{array}$ & \\
\hline NK454 & 2.97 & & & & $(1.51)^{*}$ & K-Ah \\
\hline NK457 & 6.14 & & & & & Sz-S \\
\hline NK458 & 18.06 & NK191 & 10.69 & NK268 & 3.92 & AT \\
\hline NK224 & 48.26 & NK491 & 37.54 & & $(10.28)^{*}$ & Aso-4 \\
\hline NK225 & 52.68 & & & & & $\mathrm{~K}-\mathrm{Tz}$ \\
\hline \multirow[t]{2}{*}{ NK226 } & 56.23 & & & & & Ata \\
\hline & & NK192 & 41.23 & & & SK \\
\hline NK227 & 69.83 & & & & $(16.39)^{*}$ & Aso-3 \\
\hline NK341 & 126.40 & NK299 & 84.67 & & $(26.84)^{*}$ & Ata-Th \\
\hline NK232 & 140.09 & NK193 & 97.70 & NK270 & 28.63 & Aso-1 \\
\hline NK234 & 164.59 & NK194 & 126.74 & & & Kkt \\
\hline \multirow[t]{7}{*}{ NK235 } & 181.30 & NK195 & 149.77 & NK168 & 38.57 & Unknown-a \\
\hline & & NK197 & 196.86 & NK169 & 50.45 & $\mathrm{~Kb}-\mathrm{Ks}$ \\
\hline & & NK199 & 228.70 & NK274 & 60.00 & Unknown-b \\
\hline & & NK204 & 298.37 & NK280 & 69.79 & $\mathrm{Hkd}-\mathrm{Ku}$ \\
\hline & & & & NK174 & 77.92 & Sayama \\
\hline & & NK208 & 354.53 & NK175 & 81.38 & Unknown-c \\
\hline & & NK312 & 421.80 & NK176 & 102.12 & Ss-Pink \\
\hline
\end{tabular}

*Depths are calculated by interpolation of correlation tie points with MD01-2407

the three sites. The data suggest that sedimentation at all three sites was continuous and that the sedimentation rates at Sites U1426 and U1429 were 0.23 and 1.2 times higher than at Site U1427, respectively.

\section{Oxygen isotopes at Sites U1427 and U1429}

Figure 5a shows the benthic and planktonic foraminiferal $\delta^{18} \mathrm{O}$ records of core KR07-12 PC3, which was retrieved near Site U1427. The age model of this core is based on radiocarbon measurements of planktonic foraminifera from 16 horizons and the location of the AT tephra layer. The amplitude of the negative excursion of planktonic foraminiferal $\delta^{18} \mathrm{O}$ at the LGM is similar to that reported from deeper sites in previous studies (e.g., Oba et al. 1991; Yokoyama et al. 2007). There is no significant offset between the $\delta^{18} \mathrm{O}$ values of Uvigerina spp. and Cassidulina spp. The LGM benthic and planktonic foraminiferal isotope records show low $\delta^{18} \mathrm{O}$ values, suggesting that the benthic foraminiferal $\delta^{18} \mathrm{O}$ curve at Site U1427/PC3 records surface-freshening events at glacial maxima. The peak of freshening occurred when sea level was lowest (Yokoyama et al. 2000; Mix et al. 2001). Benthic foraminiferal $\delta^{18} \mathrm{O}$ values in the upper $350 \mathrm{~m}$ of core from Site U1427 vary between 1.3 and 5.0\%o (Fig. 5b). Samples are barren of benthic foraminifera at $160-180$ and $224-245 \mathrm{~m}$. Several negative peaks are present, five of which (at 6, 50, 132, 180, and $246 \mathrm{~m}$ ) have relatively high amplitudes of $\sim 2 \%$, whereas other peaks show smaller amplitudes. The benthic isotope and sediment color $\left(b^{*}\right)$ records show similar patterns, with $\delta^{18} \mathrm{O}$ minima corresponding to $\mathrm{b}^{*}$ minima (Fig. $5 \mathrm{~b}$ ).

The $\delta^{18} \mathrm{O}$ record of ECS Site U1429 is shown in Fig. 6b. The $\delta^{18} \mathrm{O}$ values vary between 2.3 and $4.0 \%$, representing three glacial-interglacial cycles. The age model for Site U1429 was derived by correlating the benthic $\delta^{18} \mathrm{O}$ record with the LR04 global stack $\delta^{18} \mathrm{O}$ curve (Lisiecki and Raymo 2005) and by integrating tephra layers for which the eruptive ages are known. The tie points with LR04 are shown in Fig. 6b by red broken lines and are listed in Table 2. We used the ages of the following four tephra layers: K-Ah (7.2 \pm 0.1 ka: Smith et al. 2013); Sz-S ( 13 ka: Okuno 2002); AT (30.0 \pm 0.2 ka: Smith et al. 2013); and Aso-4 (87.0 \pm 0.3 ka: Aoki 2008). The K-Ah and AT tephras are widely found in marine, lacustrine, and terrestrial sediments. The stratigraphic positions of these tephras relative to the global oxygen isotope curve are well established (e.g., Oba et al. 1991; Ijiri et al. 2005; Domitsu and Oda 2006; Kubota et al. 2010). Smith et al. (2013) estimated the eruption ages of K-Ah and AT using tephra layers preserved in the sediment of Lake Suigetsu, the chronology of which has been established by varve counting with high-resolution accelerator mass spectrometry radiocarbon measurements (Bronk Ramsey et al. 2012). Radiocarbon measurements of soil just 

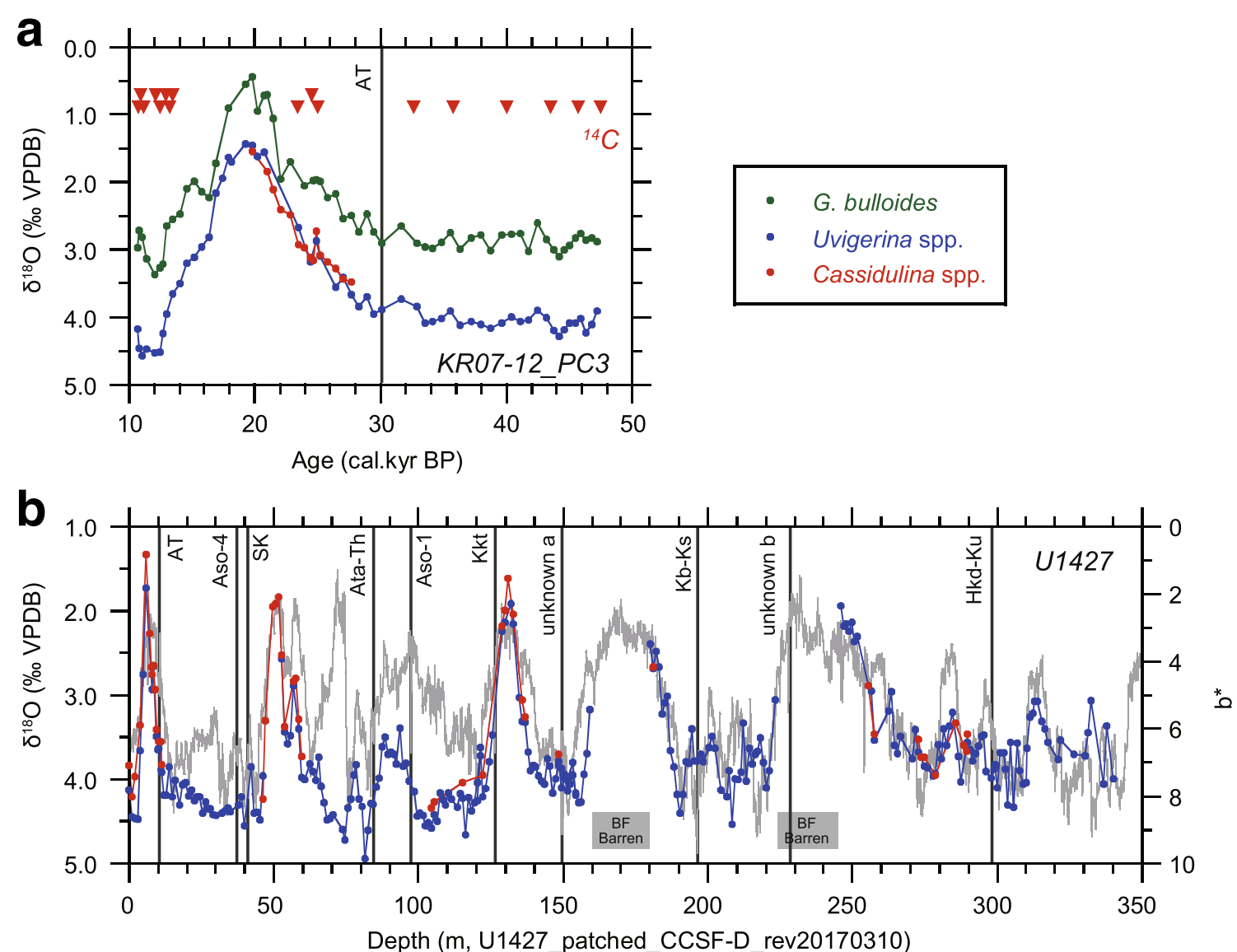

Fig. $5 \delta^{18} \mathrm{O}$ records of $\mathbf{a}$ KR07-12 PC3 and $\mathbf{b}$ Site U1427. Red triangles in a indicate the positions of planktonic foraminiferal radiocarbon dates. The gray line in $\mathbf{b}$ shows the sediment color profile $b^{*}$ at Site U1427. The vertical lines in $\mathbf{a}$ and $\mathbf{b}$ denote tephra horizons

beneath the Sz-S tephra yielded an age of $\sim 13$ cal. kyr BP (Okuno 2002). This age is consistent with the $\delta^{18} \mathrm{O}$ stratigraphy of marine core MD98-2195 (Moriwaki et al. 2011). Aoki (2008) established the stratigraphic position of the Aso-4 tephra relative to the benthic foraminiferal $\delta^{18} \mathrm{O}$ record of marine core MD01-2421 off central Japan in the Pacific Ocean. These results are in line with the $\delta^{18} \mathrm{O}$ stratigraphy of Site U1429 (Fig. 6b). The average sedimentation rate at Site U1429 is $\sim 48 \mathrm{~cm} / \mathrm{kyr}$ (Fig. 6c), and the age at the base of the site is $\sim 385 \mathrm{ka}$. The error in the correlation with LR04 is estimated to be $\pm 2.5 \mathrm{kyr}$ based on the average time resolution of the benthic $\delta^{18} \mathrm{O}$ record. The nomenclature of marine isotope stages (MISs) and substages used in this study follows Railsback et al. (2015). The benthic foraminiferal $\delta^{18} \mathrm{O}$ data at Sites U1429 and U1427 are available in Additional files 3 and 4: Table S3 and S4, respectively.

\section{Correlation of Sites U1427 and U1429}

Six tephra layers are present at Sites U1427 and U1429 (Table 1 and Fig. 2). Five of them are identified as AT, Aso-4, Ata-Th, Aso-1, and Kkt (from youngest to oldest), whereas the source volcano and eruption age of the lowest tephra, tentatively called "unknown-a" in this study, are not known. These tephra layers allow the JS and ECS benthic $\delta^{18} \mathrm{O}$ records to be constrained (Fig. 6). The unknown-a tephra at the bottom of Site U1429 is near the MIS 11/10 boundary. The Kkt tephra is near the end of MIS 10 at Site U1429 and at the end of the light $\delta^{18} \mathrm{O}$ peak at $132 \mathrm{~m}$ depth at Site U1427, suggesting that this $\delta^{18} \mathrm{O}$ peak is equivalent to MIS 10a. Two tephra layers, Aso-1 and Ata-Th, are present before and after the MIS 8 maximum at Site U1429, respectively; therefore, the small peak at $\sim 90 \mathrm{~m}$ at Site U1427 is identified as MIS 8. Two negative peaks at $\sim 58$ and $50 \mathrm{~m}$ at Site U1427, between Aso-4 and Ata-Th, are correlated to MIS 6c and 6a. The AT tephra, which was formed just prior to the LGM, has already been described. Assuming that $\delta^{18} \mathrm{O}$ minima correspond to the lowest sea levels, then the $\delta^{18} \mathrm{O}$ minima at Site U1427 during glacial periods may be correlated to $\delta^{18} \mathrm{O}$ maxima at Site U1429. The tie points for this correlation are shown in Fig. 6 (blue dotted lines) and listed in Table 3. 


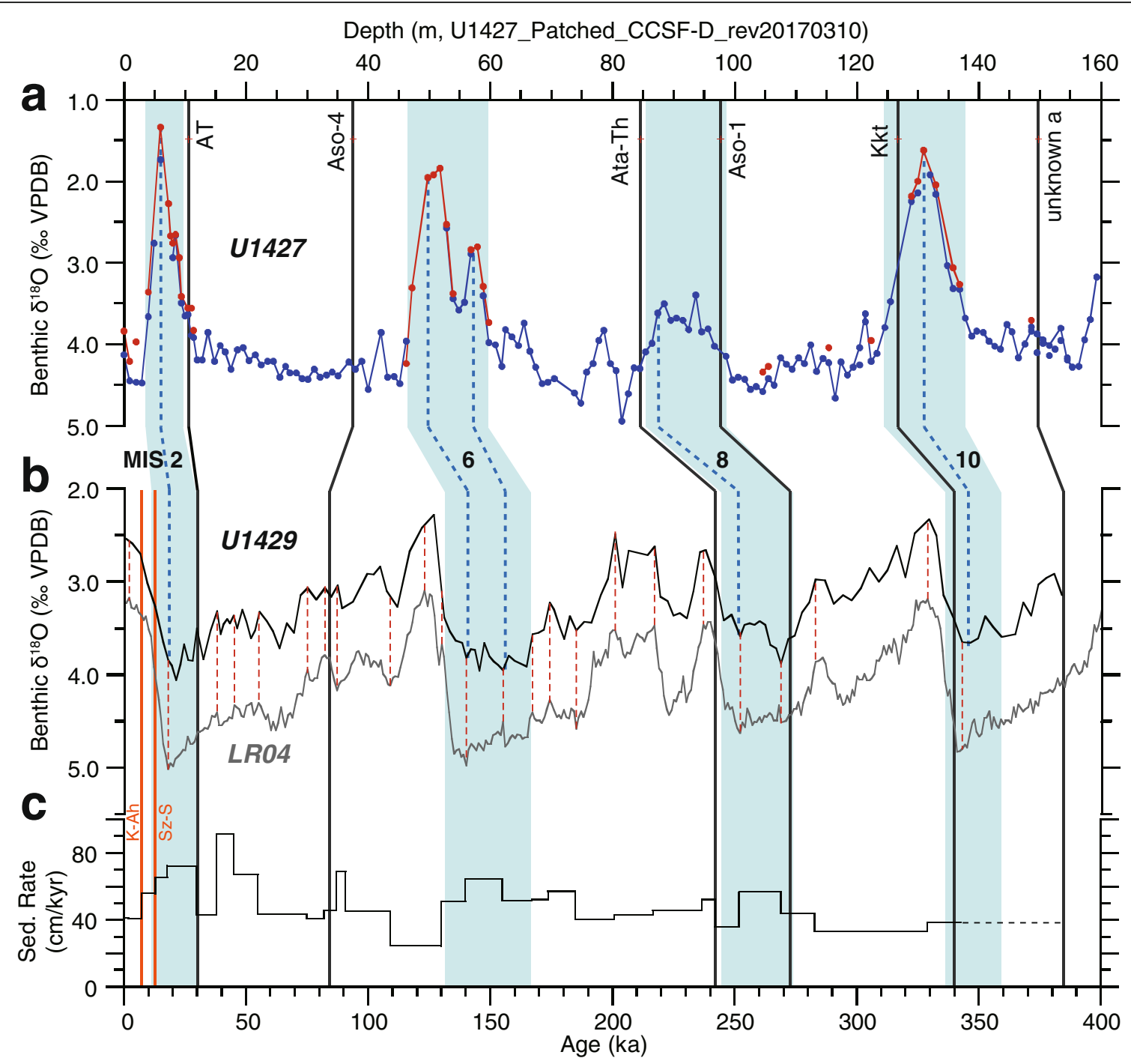

Fig. 6 Comparison of benthic foraminiferal $\delta^{18} \mathrm{O}$ records at Sites U1427 (a) and U1429 (b). Red dotted lines in b indicate age control points correlating U1429 $\delta^{18} \mathrm{O}$ measurements and the LR04 stack. c Sedimentation rate at Site U1429. The positions of two tephra layers, K-Ah and Sz-S, used to constrain the Site U1429 age model are shown by vertical lines (see text for details)

\section{Age model of Site U1427}

The age model of the sediment succession at Site U1427 was constructed by combining age constraints from benthic foraminiferal $\delta^{18} \mathrm{O}$ measurements and tephrostratigraphy, the relative abundance of subtropical microfossils, and radiolarian biostratigraphy (Figs. 7 and 8). A summary of this approach is provided in Table 4.

As discussed above, the negative peaks in benthic foraminiferal $\delta^{18} \mathrm{O}$ values at Site U1427 correlate to glacial maxima in the upper $160 \mathrm{~m}$, equivalent to the past $400 \mathrm{kyr}$ (Fig. 6). Given that eustatic change is a major cause of negative $\delta^{18} \mathrm{O}$ excursions (e.g., Oba et al. 1991; Kido et al. 2007), such a correlation is likely to be also applicable to glacial stages older than $400 \mathrm{ka}$. Two distinct negative excursions, at $\sim 180$ and $\sim 246 \mathrm{~m}$, are present below $160 \mathrm{~m}$ (Fig. 7b). The upper excursion occurs prior to MIS 10 and therefore is equivalent to MIS 12. The lower excursion corresponds to MIS 16, not to MIS 14. This interpretation is based on sea-level and ice-volume estimates which suggest that the sea-level fall during MIS 14 was less than that during MIS 16, when the ice volume was as large as during MIS 12 (Bintanja et al. 2005; Elderfield et al. 2012). Therefore, the sea-level drop at MIS 14 is likely to have resulted in less intense surface freshening in the absence of a strong negative $\delta^{18} \mathrm{O}$ excursion. The two zones that lack benthic foraminifera at 160-180 and 224-245 m occur just above negative excursions and correspond to intervals of laminated sediment. The shipboard data show that all microfossil groups, except diatoms, are rare or absent in these intervals (Tada et al. 2015a). Taking into account the higher abundance of freshwater diatom species in these intervals (Tada et al. 2015a), we suggest that surface water freshening during 
Table 2 Correlation tie points between Sites U1429 and LR04

\begin{tabular}{|c|c|}
\hline U1429 depth (m, CCSF-D) & Age (kyr) \\
\hline 0.82 & 2 \\
\hline 2.97 & 7.3 \\
\hline 6.14 & 13 \\
\hline 9.40 & 18 \\
\hline 18.06 & 30 \\
\hline 21.48 & 38 \\
\hline 27.85 & 45 \\
\hline 34.55 & 55 \\
\hline 43.14 & 75 \\
\hline 45.99 & 82 \\
\hline 48.26 & 87 \\
\hline 51.00 & 91 \\
\hline 53.11 & 91 \\
\hline 61.18 & 109 \\
\hline 64.56 & 123 \\
\hline 66.24 & 130 \\
\hline 71.34 & 140 \\
\hline 81.00 & 155 \\
\hline 87.14 & 167 \\
\hline 90.75 & 174 \\
\hline 97.04 & 185 \\
\hline 103.46 & 201 \\
\hline 110.29 & 217 \\
\hline 119.40 & 237 \\
\hline 122.00 & 242 \\
\hline 126.40 & 242 \\
\hline 130.00 & 252 \\
\hline 139.58 & 269 \\
\hline 145.70 & 283 \\
\hline 160.72 & 329 \\
\hline 166.04 & 343 \\
\hline
\end{tabular}

these two glacial maxima was too extreme for some marine groups.

The trend of benthic foraminiferal $\delta^{18} \mathrm{O}$ variations at Site U1427 closely follows the sediment color reflectance $\mathrm{b}^{*}$ data (Fig. 5b). All negative excursions in $\delta^{18} \mathrm{O}$ values correspond to $b^{*}$ minima. The $b^{*}$ variation shows a negative correlation with natural gamma radiation (NGR) and MS trends and a positive correlation with the relative abundance of biogenic components such as calcareous nannofossils (figure F13 in Tada et al. 2015a). Since NGR and MS values reflect terrigenous clastic content and show a negative correlation with biogenic component abundance, $b *$ is interpreted to reflect the ratio of biogenic to terrigenous input. As Site U1427 is on the outer margin
Table 3 Correlation tie points between Sites U1427 and U1429

\begin{tabular}{llll}
\hline $\begin{array}{l}\text { U1427 depth (m, U1427_- } \\
\begin{array}{l}\text { Patched_CCSF-D_ } \\
\text { rev20170310) }\end{array}\end{array}$ & $\begin{array}{l}\text { U1429 depth } \\
(\mathrm{m}, \text { CCSF-D })\end{array}$ & U1429 Age (ka) & Event \\
\hline 0.00 & 0.0 & 0.0 & Core top \\
6.01 & 9.40 & 18.0 & MIS 2 \\
10.69 & 18.06 & 30.0 & AT \\
37.54 & 48.26 & 87.0 & Aso-4 \\
50.78 & 71.34 & 140.0 & MIS 6a \\
57.84 & 81.00 & 155.0 & MIS 6c \\
84.67 & 126.40 & 242.0 & Ata-Th \\
88.51 & 130.00 & 252.0 & MIS 8 \\
97.70 & 140.09 & 270.2 & Aso-1 \\
126.74 & 164.59 & 339.2 & Kkt \\
131.00 & 167.18 & 346.0 & MIS 10 \\
149.77 & 181.30 & 383.2 & Unknown-a \\
& & & tephra
\end{tabular}

of the marginal terrace $(\sim 330 \mathrm{mbsl})$, terrigenous input at this site is likely to be strongly controlled by sea-level variability. Therefore, $\delta^{18} \mathrm{O}$ values and $\mathrm{b}^{*}$ should exhibit similar variations on glacial-interglacial time scales. However, two $\mathrm{b}^{*}$ minima are present at $\sim 30 \mathrm{~m}$ and $\sim 70 \mathrm{~m}$ that are not associated with a negative $\delta^{18} \mathrm{O}$ excursion (Fig. 5b). The sediment in these intervals is characterized by black to very dark greenish-gray clayey silt with heavy bioturbation, with an appearance that is not typical of glacial maxima (Tada et al. 2015a). Nevertheless, assuming that sea-level falls at glacial maxima are typically accompanied by $b^{*}$ minima, then the MIS 12 and 16 glacial maxima are at 167.2 and $232.0 \mathrm{~m}$, respectively (Fig. 7 and Table 4). In the absence of a stable-isotope record below $350 \mathrm{~m}$, we have correlated $b *$ minima to glacial maxima, with MIS 24-22 at 345-370 $\mathrm{m}$ and MIS 26 at $382 \mathrm{~m}$.

The regional tephra layers also constrain the age of sediment in this section. We used four tephra layers (AT, Aso-4, Hkd-Ku, and Ss-Pink) for which the relative positions in the stable isotope stratigraphy are known. Pickering et al. (1999) established a stable isotope stratigraphy and magnetostratigraphy for the deep-marine successions of the middle Kazusa Group in the Yoro River section in southeast Japan. The stratigraphic position of the Ku1 tephra, which is also known as the Hkd-Ku tephra (Satoguchi and Nagahashi 2012), is at the base of MIS 18, slightly above the BrunhesMatuyama boundary (Pickering et al. 1999). Based on this, the two minor negative $\delta^{18} \mathrm{O}$ peaks at 284.7 and $295.4 \mathrm{~m}$, above the $\mathrm{Hkd}-\mathrm{Ku}$ tephra layer, correspond to MIS 18, and the $\delta^{18} \mathrm{O}$ minimum below $\mathrm{Hkd}-\mathrm{Ku}$ at $314.1 \mathrm{~m}$ is the MIS 20 maximum. The Ss-Pink lies in the Jaramillo Subchron in lacustrine deposits of the Osaka and Kazusa groups (Torii et al. 1974; Hayashida et al. 


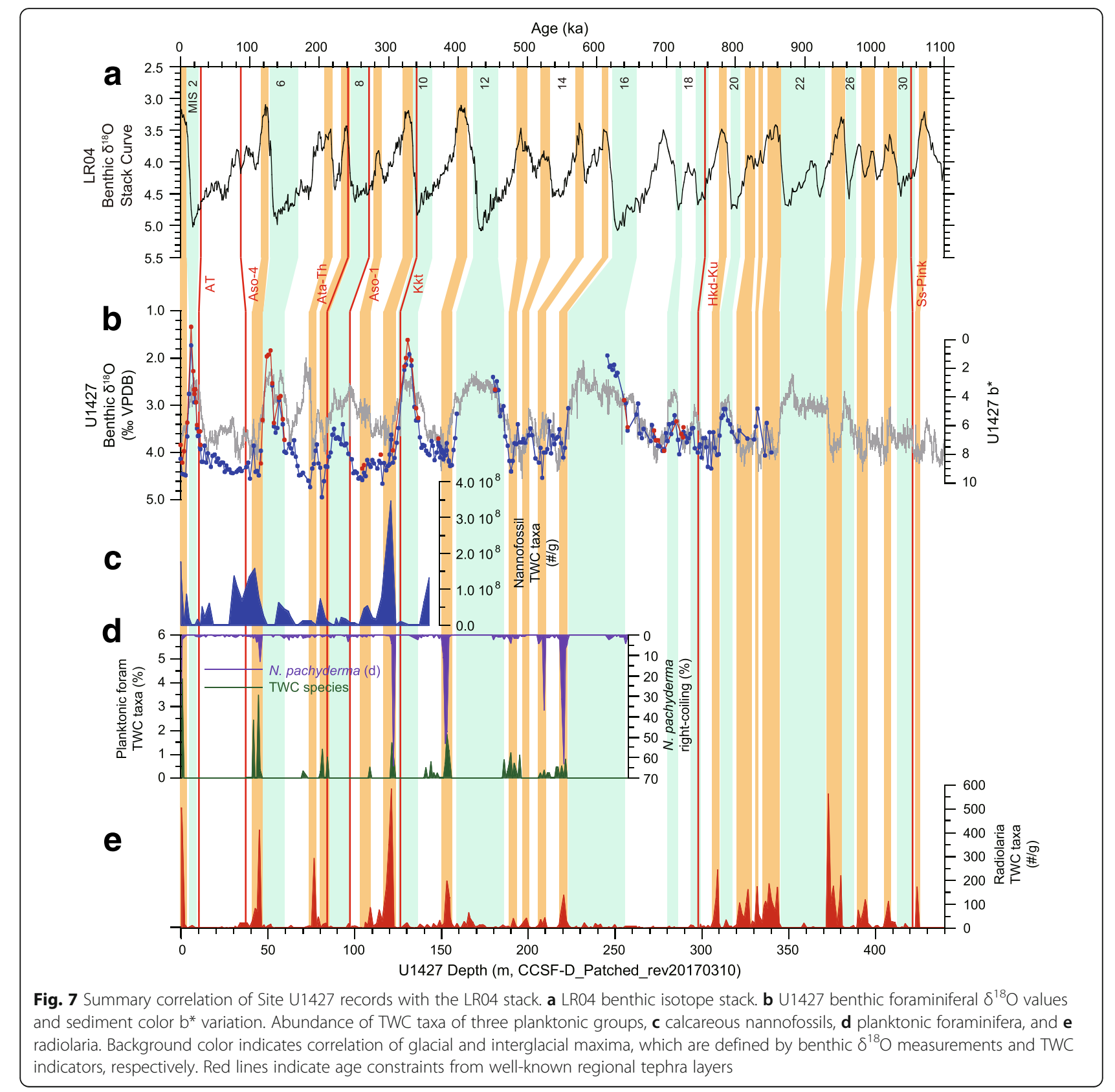

1996). High-resolution chronostratigraphic analyses suggest that the stratigraphic position of the $\mathrm{O} 7$ tephra in the Kazusa Group, which is also known as the Ss-Pink tephra (Satoguchi and Nagahashi 2012), is in the early part of MIS 30, and the age of this tephra is 1.050$1.056 \mathrm{Ma}$ (Tsuji et al. 2005).

To further constrain the stratigraphy, we used ingressions of subtropical TWC species of planktonic microfossils to calibrate interglacial maxima. The relative abundance of TWC indicators of these three microfossil groups (calcareous nannofossils, planktonic foraminifera, and radiolarians) generally show good correlations (Fig. 7c-e). The broader peaks of calcareous nannofossil abundance are due to the lower resolution of this part of the study. The higher abundance is only observed in calcareous nannofossils at 12-17, 32, and 57-63 m (Fig. 7c), possibly due to nutrient availability as well as differences in habitat depths between the various microfossil proxies. Calcareous nannoplankton are limited to the photic zone due to photosynthesis, whereas zooplankton dwell in a wide range of depths (e.g., Fairbanks et al. 1980; Itaki 2003; Itaki et al. 2003; Kuroyanagi and Kawahata 2004). Global sea-level records suggest that the amount of sea-level lowering at glacial maxima was comparable to the sill depth of the modern Tsushima Strait (Siddall et al. 2003; Rohling et al. 2014). In other words, the sea level at other periods was sufficiently high to allow 


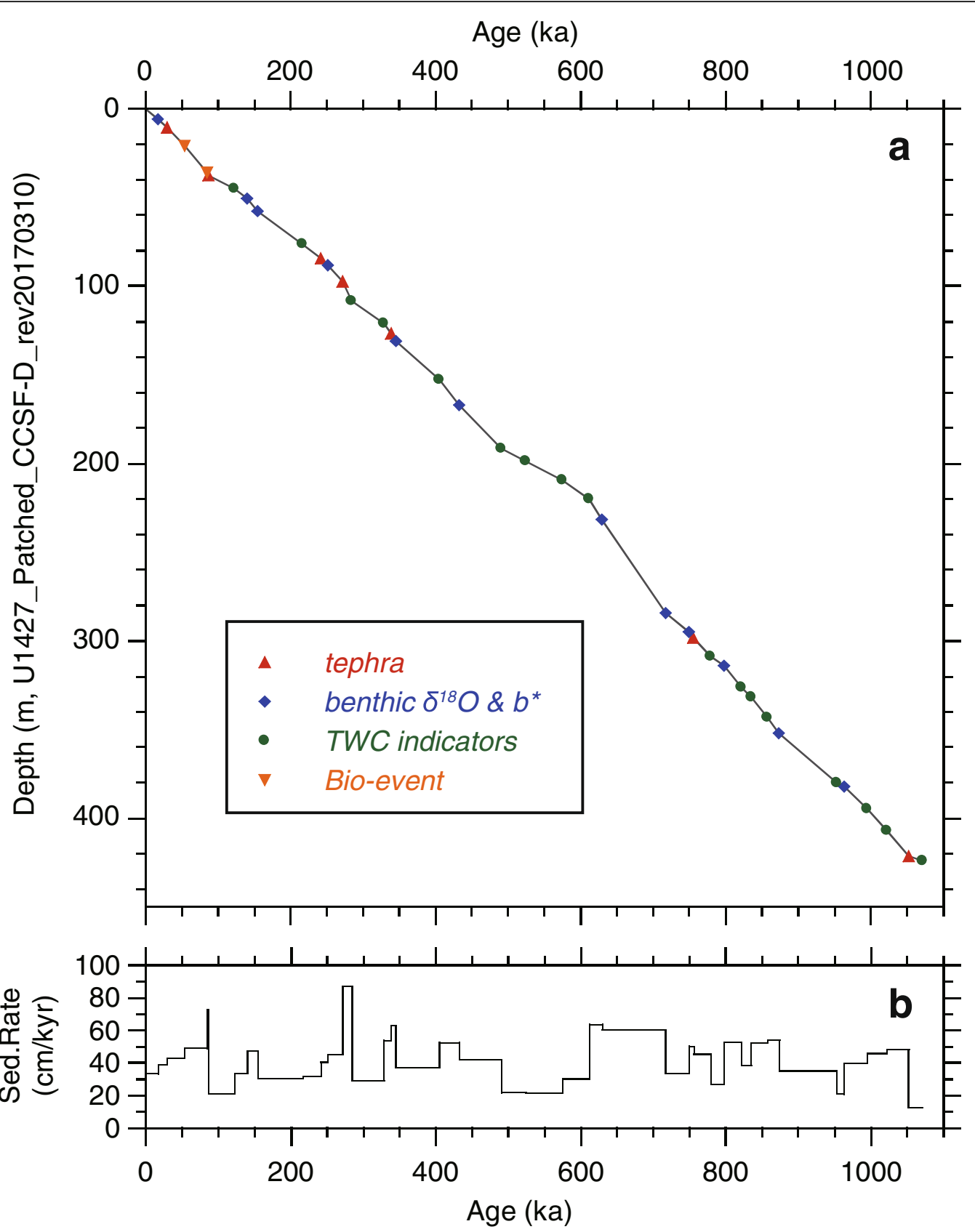

Fig. 8 Age-depth relationship at Site U1427 (a) and sedimentation rate (b)

surface water to flow in through the strait. Given that the TWC indicators of zooplankton groups show peaks with short durations just after glacial maxima, substantial inflow of the TWC only occurred during interglacial maxima. Therefore, maxima in calcareous nannofossils that are not present in the other microfossil groups could suggest that the sea level was not as high as at the present day and that the depth of the Tsushima Strait was limited to only a few tens of meters, preventing zooplankton from migrating through the strait. Therefore, we interpret the peaks of zooplankton just after the glacial negative $\delta^{18} \mathrm{O}$ excursions as interglacial maxima (Fig. 7). All interglacials except for MIS 17 show higher abundances of subtropical species compared with glacial periods. The lack of TWC indicators during MIS 17 might relate to environmental factors outside of the JS; e.g., the northwestern Pacific region and ECS. Radiolarian assemblages in cores from the Kuroshio region yield a relatively low abundance of low- to middle-latitude species during the peak of MIS 17 compared with other interglacial maxima (Matsuzaki et al. 2015), implying that subtropical water masses had less influence on the ECS at this time compared with 
Table 4 Age control points for the succession at Site U1427

\begin{tabular}{|c|c|c|c|c|}
\hline $\begin{array}{l}\text { U1427 Depth (m, Patched_CCSF-D_ } \\
\text { rev20170310) }\end{array}$ & Age (ka) & Source & Datums & Reference \\
\hline 0 & 0 & Core top & & \\
\hline 6.01 & 18 & Benthic $\delta^{18} \mathrm{O}$ & MIS 2 & Lisiecki and Raymo (2005) \\
\hline 10.69 & 30.0 & Tephra & AT & Smith et al. (2013) \\
\hline 20.98 & 54 & Bio-event & LO Lychnocanoma sakaii & Itaki et al. (2007) \\
\hline 36.09 & 85 & Bio-event & LO Amphimelissa setosa & Itaki et al. (2007) \\
\hline 37.54 & 87.0 & Tephra & Aso-4 & Aoki (2008) \\
\hline 45.10 & 123 & TWC microfossil & MIS $5 e$ & Lisiecki and Raymo (2005) \\
\hline 50.78 & 140 & Benthic $\delta^{18} \mathrm{O}$ & MIS 6a & Lisiecki and Raymo (2005) \\
\hline 57.84 & 155 & Benthic $\delta^{18} \mathrm{O}$ & MIS $6 \mathrm{c}$ & Lisiecki and Raymo (2005) \\
\hline 76.67 & 217 & TWC microfossil & MIS 7c & Lisiecki and Raymo (2005) \\
\hline 84.67 & 242 & Tephra (tied to U1429) & Ata-Th & \\
\hline 88.51 & 252 & Benthic $\delta^{18} \mathrm{O}$ & MIS 8a & Lisiecki and Raymo (2005) \\
\hline 97.68 & 270.2 & Tephra (tied to U1429) & Aso-1 & \\
\hline 108.55 & 285 & TWC microfossil & MIS 9a & Lisiecki and Raymo (2005) \\
\hline 121.27 & 329 & TWC microfossil & MIS 9e & Lisiecki and Raymo (2005) \\
\hline 126.74 & 339.2 & Tephra (tied to U1429) & Kkt & \\
\hline 131.00 & 346 & Benthic $\delta^{18} \mathrm{O}$ & MIS 10a & Lisiecki and Raymo (2005) \\
\hline 153.05 & 406 & TWC microfossil & MIS 11c & Lisiecki and Raymo (2005) \\
\hline 167.2 & 433 & $b^{*}$ & MIS 12a & Lisiecki and Raymo (2005) \\
\hline 191.57 & 491 & TWC microfossil & MIS 13a & Lisiecki and Raymo (2005) \\
\hline 198.94 & 525 & TWC microfossil & MIS 13c & Lisiecki and Raymo (2005) \\
\hline 209.58 & 575 & TWC microfossil & MIS 15a & Lisiecki and Raymo (2005) \\
\hline 220.58 & 612 & TWC microfossil & MIS 15e & Lisiecki and Raymo (2005) \\
\hline 232.0 & 630 & $b^{*}$ & MIS 16a & Lisiecki and Raymo (2005) \\
\hline 284.65 & 718 & Benthic $\delta^{18} \mathrm{O}$ & MIS 18a & Lisiecki and Raymo (2005) \\
\hline 295.37 & 750 & Benthic $\delta^{18} \mathrm{O}$ & MIS 18e & Lisiecki and Raymo (2005) \\
\hline 298.37 & 756 & Tephra & Hkd-Ku & Pickering et al. (1999) \\
\hline 309.27 & 780 & TWC microfossil & MIS 19c & Lisiecki and Raymo (2005) \\
\hline 314.11 & 798 & Benthic $\delta^{18} \mathrm{O}$ & MIS 20b & Lisiecki and Raymo (2005) \\
\hline 326.75 & 822 & TWC microfossil & MIS 21a & Lisiecki and Raymo (2005) \\
\hline 332.13 & 836 & TWC microfossil & MIS 21c & Lisiecki and Raymo (2005) \\
\hline 343.66 & 858 & TWC microfossil & MIS $21 \mathrm{~g}$ & Lisiecki and Raymo (2005) \\
\hline 352.29 & 874 & $b^{*}$ & MIS 22 & Lisiecki and Raymo (2005) \\
\hline 380.23 & 954 & TWC microfossil & MIS 25e & Lisiecki and Raymo (2005) \\
\hline 382.30 & 964 & $b^{*}$ & MIS 26 & Lisiecki and Raymo (2005) \\
\hline 395.08 & 996 & TWC microfossil & MIS 28b & Lisiecki and Raymo (2005) \\
\hline 407.44 & 1023 & TWC microfossil & MIS 29 & Lisiecki and Raymo (2005) \\
\hline 421.80 & 1053 & Tephra & Ss-Pink & Tsuji et al. (2005) \\
\hline 424.15 & 1072 & TWC microfossil & MIS 31 & Lisiecki and Raymo (2005) \\
\hline
\end{tabular}

other interglacials. The correlation horizons between TWC microfossil data and LR04 are listed in Table 4.

Four datum levels of radiolarian marker species from Site U1427 were described by Itaki et al. 2018, and three of them are within the period considered in the present study. The last occurrences (LOs) of Lychnocanomma sakaii (Morley and Nigrini 1995) and Amphimelissa setosa (Cleve) are well-known biohorizons in the 


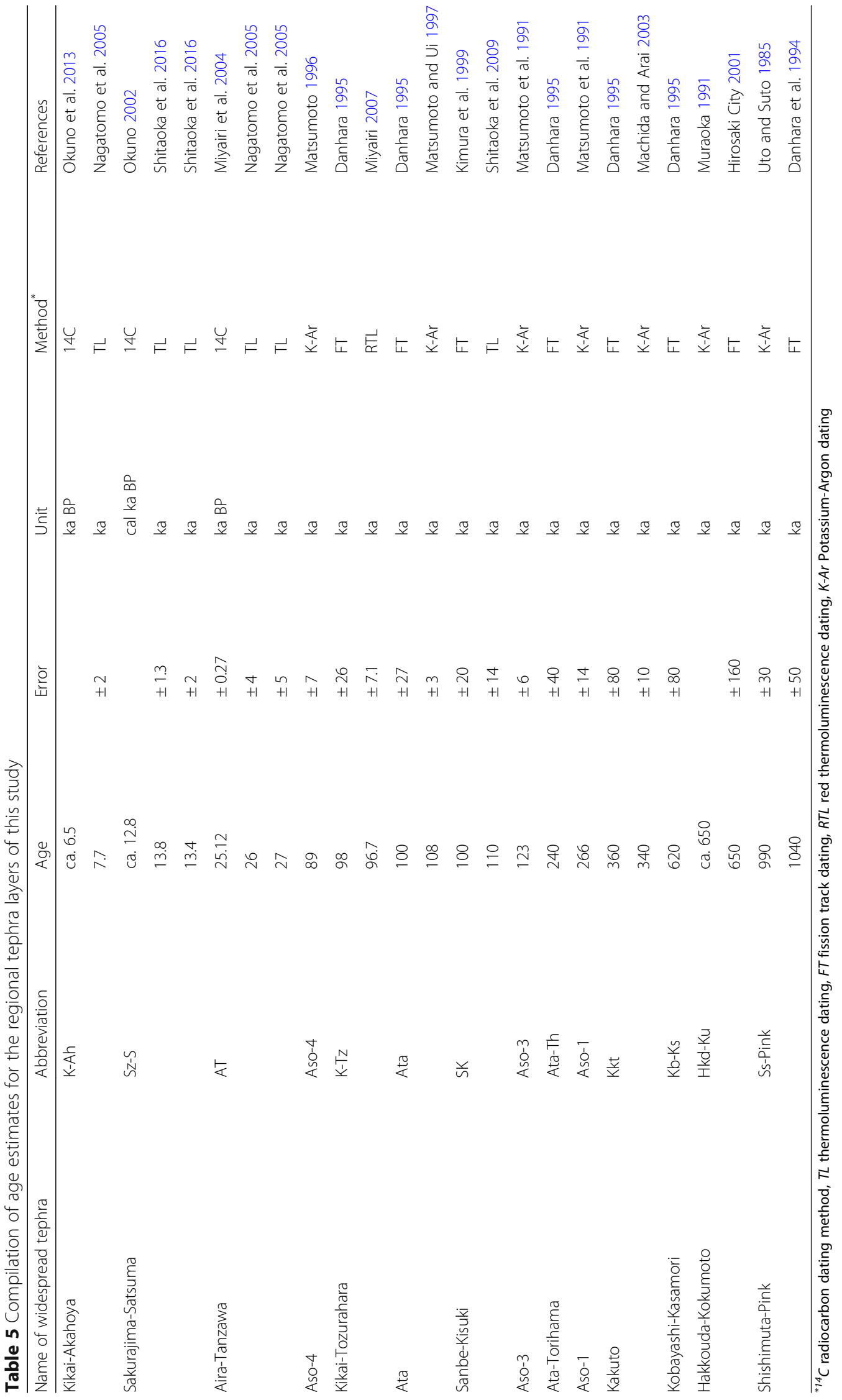


subarctic Pacific, and their estimated ages in the Japan Sea are 54 and $85 \mathrm{ka}$, respectively (Itaki et al. 2007). These datums are present at Site U1427 between two widespread tephras, AT and Aso-4. The LO of Schizodiscus japonicus Matsuzaki et al. (2014) is the same event as the LO of Spongodiscus sp. reported from the North Pacific Ocean, the Bering Sea, and the Sea of Okhotsk. In the Sea of Okhotsk, this event occurs during MIS 9 (287 ka) (Matul et al. 2002) or MIS 8c (272 ka) (Matul et al. 2009). The depth of this event at Site U1427 is between 112.05 and $112.77 \mathrm{~m}$, which is prior to the Aso-1 tephra $(272 \mathrm{ka})$ and the peak of subtropical species at MIS 9a (285 ka). Therefore, the age of $\sim 287$ ka proposed by Matul et al. (2002) appears to be likely. However, if we use the $287 \mathrm{ka}$ age for this datum, the sedimentation rates rapidly increase by a factor of $\sim 10$ across this datum, which does not appear to be geologically plausible. This may relate to a large error in the age data of Matul et al. (2002). Therefore, this datum is not included in the age model (Table 4).

The potential sources of error in the age model of Site U1427 with respect to LR04 are uncertainties in the correlation of benthic foraminiferal $\delta^{18} \mathrm{O}$ measurements and TWC indicators with LR04, and age estimations of widespread tephras and radiolarian biohorizons. The correlation of $\delta^{18} \mathrm{O}$ values and TWC indicators with LR04 would generate errors of a few thousands of years due to the resolution of the records. The errors of age estimation for tephra layers used in this study are less than \pm 1 kyr for AT and Aso-4 (Aoki 2008; Smith et al. 2013), and $\pm 3 \mathrm{kyr}$ for Hkd-Ku and Ss-Pink (Pickering et al. 1999; Tsuji et al. 2005). The ages of biohorizons are calibrated by JS planktonic foraminiferal $\delta^{18} \mathrm{O}$ values of MD01-2407 (Itaki et al. 2007), but the errors on these values are unknown. We estimated the errors of these biohorizons as $\pm 3 \mathrm{kyr}$, which includes the uncertainty of the age model of MD01-2407 (Kido et al. 2007). Including these sources of error, we estimate the uncertainty of the age model of Site U1427 to be $\pm 5 \mathrm{kyr}$ for the period $0-400 \mathrm{ka}$ and $\pm 10 \mathrm{kyr}$ for the period 400 $1000 \mathrm{ka}$.

\section{Age estimation of regional tephra layers using the newly established chronology}

Fifteen out of eighteen correlative tephra layers were identified as regional tephra layers. The ages of regional tephra layers have been previously established by several techniques using eruption products near a source volcano or regional deposits (Table 5). The tephrochronology of Pliocene to Pleistocene strata around the Japanese islands was developed using these techniques combined with biostratigraphy, magnetostratigraphy, and oxygen isotope stratigraphy (Tamura and Yamazaki 2010; Satoguchi and Nagahashi 2012). As discussed above, we only used six widespread tephra layers as age constraints, where their relative stratigraphic positions with respect to the oxygen isotope stratigraphy are known. In this section, we discuss the sedimentation ages of tephra layers that are not used as age constraints, by comparing the ages estimated in this study with those reported in previous studies. The ages estimated in this study were calculated by a simple linear interpolation method.

The K-Tz tephra, which is widespread in central and western Japan, was deposited just after MIS 5c (Machida and Arai 2003). The estimated age based on U1429 $\delta^{18} \mathrm{O}$ stratigraphy is $91 \mathrm{ka}$, which corresponds to MIS $5 \mathrm{~b}$. This estimate is within error of the results of fission-track (FT) analyses (98 $\pm 26 \mathrm{ka}$, Danhara 1995) and the red thermoluminescence method (93.7 $\pm 7.1 \mathrm{ka}$, Miyairi 2007) (Table 5).

The stratigraphic position of the Ata tephra in marine sediment was previously reported to be between MIS $5 \mathrm{~d}$ and 5c, with an estimated age of 103-107 ka (Oba 1991). Our estimate is $98 \mathrm{ka}$, which is younger than the value suggested by Oba (1991) and the K-Ar age of pyroclastic flow deposits (108 $\pm 3 \mathrm{ka}$, Matsumoto and Ui 1997).

Chun et al. (2004) reported the Aso-3 tephra layer in marine sediment cores from the Ulleung Basin, in a bioturbated mud just above a dark finely laminated layer deposited during MIS 6a. Nagahashi et al. (2004) reported the Aso-3 tephra from an interval with an estimated age of $133 \mathrm{ka}$ below MIS 5e in marine clay in cores from the Osaka coast. The stratigraphic position of Aso-3 at Site U1429 agrees with these results, and the estimated age of $\sim 137 \mathrm{ka}$ is also consistent with previous studies.

The Ata-Th tephra layer is prior to MIS 7e. In the present study, its age is estimated to be $242 \mathrm{ka}$. This agrees with its estimated age in lacustrine sediment from Lake Biwa (238 ka, Yoshikawa and Kuwae 2001) and FT analyses (240 $\pm 40 \mathrm{ka}$, Danhara 1995).

The Aso-1 tephra lies beneath the maximum $\delta^{18} \mathrm{O}$ value in MIS 8 (Fig. 6). We suggest that this $\delta^{18} \mathrm{O}$ maximum correlates to MIS $8 \mathrm{c}$ rather than $8 \mathrm{a}$, which is the MIS 8 maximum in the LR04 stack, as there is another positive peak at Site U1429 just below 7e (Fig. 6). The estimated age of Aso- 1 in this study is $270 \mathrm{ka}$, which is within error of a $\mathrm{K}-\mathrm{Ar}$ date $(266 \pm 14 \mathrm{ka}$, Matsumoto et al. 1991) and is older than the age estimated from Lake Biwa (249 ka, Yoshikawa and Kuwae 2001). There is a discrepancy of $\sim 21 \mathrm{kyr}$ between Site U1429 and Lake Biwa, possibly due to the large error in the Lake Biwa age estimation, as discussed later.

The Kkt tephra is present near the end of MIS 10 at Site U1429 (Fig. 6), and its age is estimated to be $339 \mathrm{ka}$, consistent with that from Lake Biwa (334 ka, Yoshikawa and Kuwae 2001) and radiometric data (Danhara 1995; Machida and Arai 2003) (Table 5). 


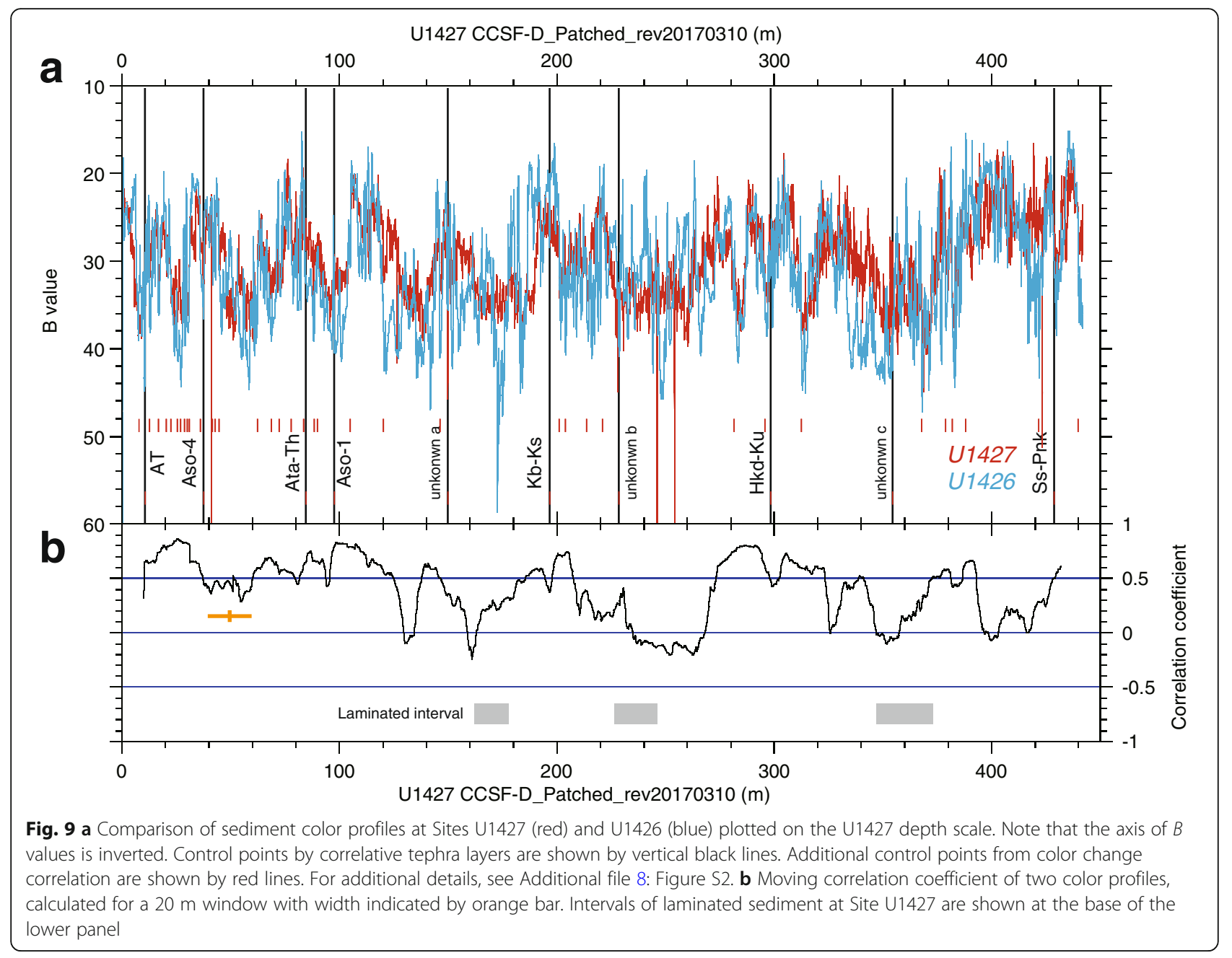

The difference in estimated ages between Site U1429 and Lake Biwa is greater for Aso-1 $(\sim 21 \mathrm{kyr})$ and smaller for Ata-Th and Kkt ( $5 \mathrm{kyr})$. The age estimate for Lake Biwa sediment is based on a change in pollen assemblage, which shows alternations of warm-temperate and coolboreal species in response to glacial-interglacial cycles (Miyoshi et al. 1999). Ata-Th and Kkt are present at transitions from cool to warm periods, and these can be correlated to terminations. However, the Aso-1 tephra occurs within a period of cool-boreal conditions, equivalent to MIS 8. As the duration of the MIS 8 cold period ( $30 \mathrm{kyr})$ is longer than that of terminations $(<8 \mathrm{kyr})$, the age estimate of Aso-1 may have a greater uncertainty than that of Ata-Th and Kkt.

The ages of the SK and Kb-Ks tephra layers, which are not present at Site U1429, are based on the Site U1427 age model. The SK tephra layer at $41.23 \mathrm{~m}$ depth at Site U1427 is $\sim 4 \mathrm{~m}$ below the Aso- 4 tephra (Fig. $5 \mathrm{~b}$ ). The estimated age of the SK tephra is $102 \mathrm{ka}$ in this study, which agrees with radiogenic data $(100 \pm 20 \mathrm{ka}$, Kimura et al. 1999; $110 \pm 14 \mathrm{ka}$, Shitaoka et al. 2009) (Table 5).
The Kb-Ks tephra layer at $196.86 \mathrm{~m}$ is within MIS 13c/ 13b (Fig. 7), and the estimated age of $516 \mathrm{ka}$ is much younger than that derived from FT analyses (620 $\pm 80 \mathrm{ka}$ : Danhara 1995). Shirai (2001) interpreted the stratigraphic position of the Kb-Ks tephra at ODP Sites 794 and 797 relative to changes in diatom abundance. The diatom abundance in the deep-sea sediment of the JS is considered to be related to sea-level change (Tada et al. 1992, 1999), which controls nutrient input through the Tsushima Strait. Therefore, variations in diatom abundance follow the $\delta^{18} \mathrm{O}$ curve, enabling estimates of sediment age. The age of $520 \pm 20 \mathrm{ka}$ (MIS 13c) estimated by Shirai (2001) shows good agreement with the result of this study (516 ka).

In this study, three equivalent tephra layers are present between sites (tentatively called unknown-a, unknown-b, and unknown-c), which were not correlated to regional tephras. The unknown-a tephra is found at three sites, and the unknown-b and unknown-c tephras occur only at Sites U1426 and U1427. The ages of these tephra layers were estimated using the age model of Site 


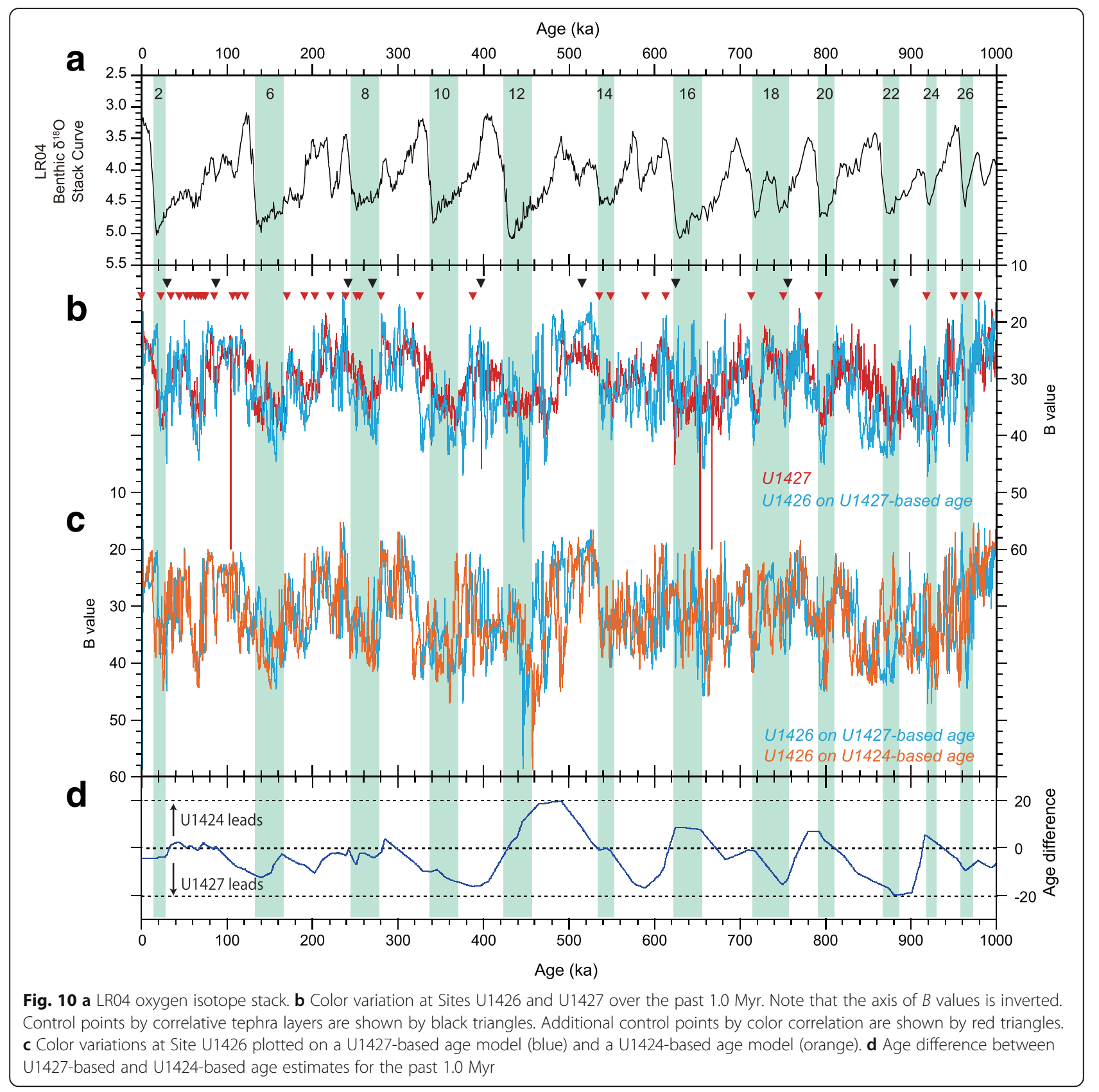

U1427. The age of the unknown-a tephra layer is $383 \mathrm{ka}$, above the distinct peaks of TWC indicators of MIS 11c (Fig. 7). The ages of the unknown-b and unknown-c tephra layers are estimated to be 625 and $880 \mathrm{ka}$, respectively. Although there is no benthic foraminiferal $\delta^{18} \mathrm{O}$ record for these intervals, both tephra layers correspond to $b^{*}$ minima, suggesting that they were erupted during the glacial maxima of MIS 16 and 22. The stratigraphic positions of these three unidentified tephra layers are in MIS 11, 16, and 22, respectively, and they may be useful for correlating sediment successions at other locations.

\section{Correlation of Sites U1426 and U1427}

Eight tephra layers are present at Sites U1426 and U1427 (Table 1 and Fig. 2). Although the widespread tephra layers of K-Ah, Aso-4, Aso-3, and Ata-Th are not present at Site U1426, Kido et al. (2007) reported these tephras in core MD01-2427, $10 \mathrm{~km}$ away. Since the two sites are adjacent and the color variations of the sediments are similar (Additional file 5: Figure S1), the stratigraphic positions of the tephra layers in core MD01-2407 can be correlated to Site U1426 using sediment color profiles (Additional file 6: Table S5). Therefore, two more widespread tephra layers, Aso-4 
and Ata-Th, can also be used to correlate features between Sites U1426 and U1427.

We attempted to correlate the color variations of sediment at Sites U1426 and U1427 using tephra layers as primary correlation horizons. As noted above, the decimeter-scale dark and light color alternations at Site U1426 are distinctive, whereas color variability at Site U1427 is less obvious and more gradual. To highlight color changes at Site U1427, the brightness and contrast in photographs of sediment surfaces were enhanced (Fig. 2). These enhanced photographs clearly show meter-scale color variations at Site U1427.

The color variations of sediments in deeper-water sites have been well documented (Tada et al. 1992; Kido et al. 2007). The fact that dark-light alternation is commonly observed and correlated in the JS indicates that it reflects a basin-wide phenomenon (e.g., Nakajima et al. 1996). Previous studies have shown that the brightness $\left(\mathrm{L}^{*}\right)$ at deeper sites correlates well to the total organic carbon (TOC) content, except during glacial maxima (Tada et al. 1992; Kido et al. 2007), when finely laminated dark layers were deposited under euxinic conditions due to density stratification in the JS, and TOC was relatively low. Black and Anderson (2017) showed that the $L^{*}$ and B values of Site U1427 correlate well with the TOC content. Therefore, TOC seems to be the major component contributing to the dark sediment color at deeper and shallower sites, suggesting that correlation using color profiles is reasonable.

Figure 9 shows the $B$ values of RGB correlation between Sites U1426 and U1427. These cores are correlated using shipboard line-scan images of the sediment surface and RGB data at $0.05 \mathrm{~mm}$ intervals, and a $3 \mathrm{~cm}$ moving average of $5 \mathrm{~mm}$ resolution data for Site U1426 and a $10 \mathrm{~cm}$ moving average of $5 \mathrm{~mm}$ resolution data for Site U1427. The overall variations in RGB reflect sediment brightness. Therefore, similar to $\mathrm{L}^{*}, \mathrm{RGB}$ appears to reflect TOC. Ten tephra layers were used as primary tie points in Fig. 9, and additional tie points were selected based on $B$ value trends (Additional file 7 : Table S6). A detailed comparison of the color profiles at the two sites is shown in Additional file 8: Figure S2. Overall, the color variations appear to correlate well (see the running correlation coefficient calculated using a window with $20 \mathrm{~m}$ width in Fig. 9b). The average correlation coefficient over the whole interval is $\sim 0.4$. Five intervals at $\sim 130,160,220-265,345-370$, and $395-425 \mathrm{~m}$ do not correlate (Fig. 9). Based on our age model, these five intervals correspond to the glacial periods of MIS 10, 12, 16, 22, and 28-30 (Fig. 7). Three glacial periods (MIS 12, 16, and 22) correspond to faintly laminated intervals, where benthic foraminifera are sparse or absent (Tada et al. 2015a), suggesting that intermediate water properties were significantly different during these periods compared with other times. The poor correlation between shallow- and deep-sediment colors during glacial periods is likely due to the fact that the process of dark layer formation during glacial maxima differed from the process that operated during other periods. During glacial maxima, thick dark layers with fine laminations were caused by stagnant euxinic deep water due to a strong density stratification, which was not accompanied by high TOC. Ikehara et al. (1994) suggested that the thick dark layer deposited during the LGM only occurs in water depths greater than $500 \mathrm{~m}$, suggesting that the redox boundary was below $\sim 500 \mathrm{~m}$ and that environments below and above this depth were quite different during glacial maxima compared with other periods.

We constructed an age model for Site U1427 and attempted to correlate the color profiles between Sites U1427 and U1426. Although the correlation of the two sites is not always significant, ten correlative tephra layers provide robust ties at least for the glacial-interglacial intervals. The depth-scale of Site U1426 was converted to an age scale via correlation with Site U1427. The $B$ value variations at Sites U1426 and U1427 over the past 1.0 Myr are shown in Fig. 10b. The $B$ values show orbitalscale variations at both shallow and intermediate depths in the JS, where sediment colors are lighter during glacials and darker during interglacials. Given that the sediment color reflects the TOC content of the sediment, the overall pattern suggests that productivity was higher during interglacials, probably due to an increased input of nutrients from the ECS during periods of high sea level in contrast to glacial periods, when the JS was almost entirely cut off from the ECS (Tada et al. 1999).

\section{Evaluation of age models}

Combining several kinds of age constraints enabled us to establish the orbital-scale age model of the shallow Site U1427, and this chronology was transferred to the deeper Site U1426 by correlating sediment color profiles (Fig. 9). The sediments at the six deeper sites (U1422U1426 and U1430) drilled during Expedition 346 are characterized by dark-light alternations. As noted above, the sporadic occurrence of foraminiferal tests made it difficult to establish a stable isotope stratigraphy for the deeper sites. Therefore, age estimation for deeper sites was attempted using a different approach (Tada et al. 2018). To evaluate and understand the limitations of the various approaches, we compared two independent age models that are based on different concepts.

Tada et al. (2018) derived an age model for Site U1424 based on the magnetostratigraphy, tephrochronology, and tuning of physical properties to the LR04 stack. Physical properties, such as gamma ray attenuation (GRA), bulk density, and NGR, in deeper cores are considered to reflect diatom content because of their highinternal porosity (Tada and Iijima 1983) and the effect of dilution of detrital materials. The diatom content in the 
IS sediment is thought to be strongly related to eustatic sea-level changes, which constrained nutrient influx into the sea as well as subsequent diatom production (Tada et al. 1992, 1999). Therefore, GRA and NGR data reflect sea-level changes and are useful in identifying marine isotope stages. Correlation of Site U1424 to the LR04 stack was achieved by relating the variability in physical properties to glacial maxima over the past 3 Myr (Tada et al. 2018). Tada et al. (2018) also correlated the six deeper sites using distinct, relatively thick dark layers, magnetostratigraphy, and tephra layers. As a result, 64 horizons can be correlated for the past 1.5 Myr. This inter-site correlation enables us to transfer the age model of Site U1424 to all deeper sites, including Site U1426. Thus, two independent age estimations are available for Site U1426, based on the correlation of dark layers with Site U1424 and the correlation of color variations with Site U1427. Figure 10c-d compares age models and age differences between these approaches. The age difference is calculated by subtracting U1424-based ages from U1427-based ages, and this is plotted against the U1427based age model. Positive values indicate that the U1424based age model leads the U1427-based model.

The age estimates for Site U1426 obtained using two different methods show good agreement for the past $300 \mathrm{kyr}$ (Fig. 10), when more tie points of color variations at Sites U1426 and U1427 are available compared with the older intervals (red triangles in Fig. 10b). Large discrepancies $(\sim 20$ $\mathrm{kyr}$ ) are present at MIS 11, 13-12, 15, and 22. The discrepancies during interglacial stages (MIS 11 and 15) are probably due to the lack of age control points for interglacials at Site U1424. Since the correlation of physical properties between Sites U1424 and LR04 is based on glacial peaks, ages of interglacial maxima were calculated by interpolation using a constant sedimentation rate (Tada et al. 2018). In contrast, the interglacials at Site U1427 are well constrained using the high abundance of TWC taxa (Fig. 7). The poor correlation during interglacials would be improved if the constraints provided by TWC indicators were available for the deeper sites. The age discrepancies during glacial stages (MIS 13-12 and 22) are probably due to lack of color correlation tie points between Sites U1426 and U1427. As discussed above, the sediments of MIS 12, 16, and 22 are faintly laminated at Site U1427 and differ markedly from the equivalent sediments at Site U1426 (Fig. 9). Furthermore, the interval of MIS 13-12 is characterized by large changes in calcium carbonate content at deeper sites (Kido et al. 2007; Khim et al. 2014), which are not present at the shallower Site U1427. Therefore, no tie points are determined for these glacial periods (Fig. 10b). However, there are correlative tephra layers at MIS 22 (unknown-c) and 16 (unknown-a). Therefore, age discrepancies during these glacial periods are attributed not to poor correlation between Sites U1426 and U1427, but to correlation between LR04 and Site U1424 and/or Site U1427. Further investigation is needed to improve the age estimation of these glacial periods. Although there is up to a $20 \mathrm{kyr}$ age difference, the general agreement of the two independent age models implies that the orbital-scale variations in sediment brightness at both shallow and deep sites, which mainly reflect TOC content, were controlled by eustatic sea-level changes.

\section{Conclusions}

Two IODP Expedition 346 sites in the Japan Sea and the northern East China Sea are correlated on a glacio-eustatic orbital scale for the first time. Detailed morphological, mineralogical, and elemental-composition analyses of tephras enhance the chronostratigraphic basis of this correlation. Eighteen tephra layers were identified that can be correlated between sites or to other well-known tephras. The results suggest that glacial surface water in the Japan Sea was much fresher than that in the East China Sea. Several microfossil proxy records show strong variability that is directly related to glacial-interglacial sea-level change. The age model for the upper part of Site U1427 suggests that the top $430 \mathrm{~m}$ is younger than $1100 \mathrm{ka}$. Despite the lack of distinct dark-light alternations, the subtle color variations at the shallow Site U1427 generally correlate to color variations at the deeper Site U1426 on an orbital scale, and perhaps on the millennial scale in the $120 \mathrm{kyr}$ interval. The agreement of age estimates based on two different methods supports the age models derived for Sites U1427 and U1424, and the inter-site correlation of JS sites. The intersite correlation makes it possible to compare proxy records of latitudinally and vertically distributed Expedition 346 Sites in the Japan Sea and to compare between the Japan Sea and the East China Sea.

\section{Additional files}

Additional file 1: Table S1. Major element compositions of volcanic glass shards of tephra layers investigated in this study and well-known regional tephra layers. (XLSX $27 \mathrm{~kb}$ )

Additional file 2: Table S2. Petrographic property of tephra layers investigated in this study and well-known regional tephra layers. (XLSX $20 \mathrm{~kb}$ )

Additional file 3: Table S3. Benthic foraminiferal $\delta^{18} \mathrm{O}$ results at Site U1429. (XLSX $13 \mathrm{~kb}$ )

Additional file 4: Table S4. Benthic foraminiferal $\delta^{18} \mathrm{O}$ results at Site U1427. (XLSX 15 kb)

Additional file 5: Figure S1. Correlation of sediment color profiles at two adjacent Sites U1426 and MD01-2407. (ZIP 553 kb)

Additional file 6: Table S5. Correlation tie points at Sites U1426 and MD01-2407. (XLSX 12 kb)

Additional file 7: Table S6. Correlation tie points at Sites U1426 and U1427. (XLSX $11 \mathrm{~kb}$ )

Additional file 8: Figure S2. Correlation of sediment color profiles at Sites U1426 and U1427. Control poits by correlative tephra layers are shown by black lines. Additional control points are shown by green lines. (TIFF 339 kb) 


\section{Abbreviations}

CCD: Carbonate compensation depth; CCSF: Core composite depth below seafloor; ECS: East China Sea; EDS: Energy Dispersive Spectroscopy; FT: Fission track; GRA: Gamma-ray attenuation; IODP: Integrated Ocean Drilling Program; JS: Japan Sea; LGM: Last glacial maximum; LO: Last occurrence; mbsl: Meters below sea level; MIS: Marine isotope stage; MS: Magnetic susceptibility; NGR: Natural gamma radiation; NGRL: Natural gamma radiation logger; NIST: National Institute of Standards and Technology; SEM: Scanning electron microscope; SHIL: Section Half Imaging Logger; SHMSL: Section Half Multisensor Logger; TOC: Total organic carbon; TWC: Tsushima Warm Current; VPDB: Vienna Pee Dee Belemnite; WRMSL: Whole-Round Multisensor Logger; XRF: X-ray fluorescence

\section{Acknowledgements}

We are grateful to Yasufumi Iryu and Peter Clift (journal editors) and three anonymous reviewers for their constructive comments on the manuscript. We would like to show our great appreciation to all of the scientists, technicians, and crew of DN JOIDES Resolution during IODP Expedition 346. This research used samples and data provided by the IODP. TS, T Itaki, T Irino, KI, and RT would like to thank J-DESC for financial aid supporting the IODP shipboard scientists. TS thanks Yusuke Okazaki for financial support, Reika Nakamura and Kiyoka Fujino for sample preparation, and Takuya Matsuzaki and technical staff at the Kochi Core Center for their assistance with isotope measurements. This study was performed under the cooperative research program of the Center for Advanced Marine Core Research, Kochi University (14B045, 15A024, 15B021). SJG acknowledges the support of the ANZIC IODP office and the ARC Basin Genesis Hub.

\section{Funding}

This work was partly supported by the IODP Exp. 346 After Cruise Research Program, JAMSTEC and by "Collaborative Study of Long-term Changes in the Asian Monsoon" of Program for Advancing Strategic International Networks to Accelerate the Circulation of Talented Researchers, Japan Society for the Promotion of Science. AH gratefully acknowledges institutional funding from Christian-Albrechts-University.

\section{Authors' contributions}

TS, T Irino, and RT proposed the topics. YN, YS, and KI conducted tephra analyses and correlation. TS and AH conducted stable isotope measurements. T Itaki, SJG, and MSP conducted microfossil assemblage analyses. All authors contributed to the writing of the manuscript and read, discussed, and approved the final version of the manuscript.

\section{Competing interests}

The authors declare that they have no competing interests.

\section{Publisher's Note}

Springer Nature remains neutral with regard to jurisdictional claims in published maps and institutional affiliations.

\begin{abstract}
Author details
${ }^{1}$ Institute of Science and Engineering, Kanazawa University, Kakuma-machi, Kanazawa, Ishikawa 920-1192, Japan. ${ }^{2}$ Faculty of Symbiotic Systems Science, Fukushima University, 1 Kanayagawa, Fukushima, Fukushima 960-1296, Japan. ${ }^{3}$ Lake Biwa Museum, 1091 Oroshimo, Kusatsu, Shiga 525-0001, Japan. ${ }^{4}$ Institute of Geosciences, Christian-Albrechts-University, Ludewig-Meyn-Str. 10, 24118 Kiel, Germany. ${ }^{5}$ Geological Survey of Japan, National Institute of Advanced Industrial Science and Technology, 1-1-1 Higashi, Tsukuba, Ibaraki 305-8567, Japan. ${ }^{6}$ School of Earth Sciences, The University of Melbourne, Melbourne, Victoria 3010, Australia. 'Department of Geosciences, FB5, University of Bremen, Klagenfurter Strasse, 28359 Bremen, Germany. ${ }^{8}$ Faculty of Environmental Earth Science, Hokkaido University, N10W5, Sapporo, Hokkaido 060-0810, Japan. ${ }^{9}$ Department of Earth and Planetary Science, The University of Tokyo, 7-3-1 Hongo, Bunkyo-ku, Tokyo 113-0033, Japan.
\end{abstract}

Received: 30 August 2017 Accepted: 8 January 2018 Published online: 22 March 2018

\section{References}

Andruleit H (1996) A filtration technique for quantitative studies of coccoliths. Micropaleontol 42:403-406
Aoki K (2008) Revised age and distribution of ca. 87 ka Aso-4 tephra based on new evidence from the northwest Pacific Ocean. Quat Int 178:100-118

Bintanja R, van de Wal RSW, Oerlemans J (2005) Modelled atmospheric temperatures and global sea levels over the past million years. Nature 437:125-128

Black HD, Anderson WT, (2017) Organic matter contents and paleoproductivity variation within late Pleistocene Japan Sea/East Sea sediments: results from IODP Expedition 346, Abstract [PP23C-1320] presented at 2017 Fall Meeting, AGU, New Orleans, LA, 11-15 Dec.

Bronk Ramsey C, Staff RA, Bryant CL, Brock F, Kitagawa H, van der Plicht J, Schlolaut G, Marshall MH, Brauer A, Lamb HF, Payne RL, Tarasov PE, Haraguchi T, Gotanda K, Yonenobu H, Yokoyama Y, Tada R, Nakagawa T (2012) A complete terrestrial radiocarbon record for 11.2 to $52.8 \mathrm{kyr}$ B.P. Science 338:370-374

Chun J-H, Ikehara K, Sang-Joon H (2004) Evidence in Ulleung basin sediment cores for a termination II (penultimate deglaciation) eruption of the Aso-3 tephra. Quat Res (Daiyonki-Kenkyu) 43:99-112

Danhara T (1995) Towards precise measurement of zircon and glass fission-track geochronology for quaternary tephras. Quat Res (Daiyonki-Kenkyu) 34:221237 (in Japanese with English abstract)

Danhara T, Kamata H, Hayashida A, Iwano H, Yamashita T (1994) Additional data for age and correlation about OGPK, pink volcanic ash in the Osaka Group, as candidates of standard sample in Japan (part 4), fission-track news letter, pp 18-22 (in Japanese)

Darling KF, Kucera M, Kroon D, Wade CM (2006) A resolution for the coiling direction paradox in Neogloboquadrina pachyderma. Paleoceanography 21: PA2011. https://doi.org/10.1029/2005PA001189

Domitsu H, Oda M (2005) Japan Sea planktic foraminifera in surface sediments: geographical distribution and relationships to surface water mass. Paleontol Res 9:255-270

Domitsu H, Oda M (2006) Linkages between surface and deep circulations in the southern Japan Sea during the last 27,000 years: evidence from planktic foraminiferal assemblages and stable isotope records. Mar Micropaleontol 61:155-170

Elderfield H, Ferretti P, Greaves M, Crowhurst S, McCave IN, Hodell D, Piotrowski AM (2012) Evolution of ocean temperature and ice volume through the midPleistocene climate transition. Science 337:704-709

Fairbanks RG, Wiebe PH, Bé AWH (1980) Vertical distribution and isotopic composition of living planktonic foraminifera in the western north Atlantic. Science 207:61-63

Gallagher S, Kitamura A, Iryu Y, Itaki T, Koizumi I, Hoiles P (2015) The Pliocene to recent history of the Kuroshio and Tsushima Currents: a multi-proxy approach. Prog Earth Planet Sci 2:17. https://doi.org/10.1186/s40645-015-0045-6

Harker A (1909) The natural history of igneous rocks. Methuen \& co., London, p 458

Hayashida A, Kamata H, Danhara T (1996) Correlation of widespread tephra deposits based on paleomagnetic directions: link between a volcanic field and sedimentary sequences in Japan. Quat Int 34-36:89-98

Hirosaki City (2001) History of Hirosaki city, new edition -overview of history 1- (in Japanese), p 425

ljiri A, Wang L, Oba T, Kawahata H, Huang CY, Huang CY (2005) Paleoenvironmental changes in the northern area of the East China Sea during the past 42,000 years. Palaeogeogr Palaeoclimatol Palaeoecol 219:239-261

Ikehara K (2015) Marine tephra in the Japan Sea sediments as a tool for paleoceanography and paleoclimatology. Prog Earth Planet Sci 2:36. https:// doi.org/10.1186/s40645-015-0068-z

Ikehara K, Kikkawa K, Katayama H, Seto K, (1994) Late Quaternary paleoceanography of the Japan Sea: a tephrochronological and sedimentlogical study. Proc., 29th Int'l. Geol. Congr., Part B:229-235

Irino T, Tada R, Ikehara K, Sagawa T, Karasuda A, Kurokawa S, Seki A, Lu S 2018 Construction of perfectly continuous records of physical properties for darklight sediment sequences collected from the Japan Sea during Integrated Ocean Drilling Program Expedition 346 and their potential utilities as paleoceanographic studies. Progress in Earth and Planetary Science [in press]. https://doi.org/10.1186/s40645-018-0176-7

Itaki T (2003) Depth-related radiolarian assemblage in the water-column and surface sediments of the Japan Sea. Mar Micropaleontol 47:253-270

Itaki T (2007) Historical changes of deep-sea radiolarians in the Japan Sea during the last 640 kyrs. Fossils 82:43-51 (in Japanese with English abstract)

Itaki T, Ito M, Narita H, Ahagon N, Sakai H (2003) Depth distribution of radiolarians from the Chukchi and Beaufort Seas, western Arctic. Deep-Sea Res, Part I 50:1507-1522 
Itaki T, Komatsu N, Motoyama I (2007) Orbital- and millennial-scale changes of radiolarian assemblages during the last 220 kyrs in the Japan Sea. Palaeogeogr Palaeoclimatol Palaeoecol 247:115-130

Itaki T, Sagawa T, Kubota Y, Pleistocene radiolarian biostratigraphy, IODP Expedition 346 Site U1427. In Tada, R., Murray, R.W., Alvarez Zarikian, C.A., and the Expedition 346 Scientists, Proceedings of the Integrated Ocean Drilling Program, 346: College Station, TX (Integrated Ocean Drilling Program) [in press]. https://doi.org/10.2204/iodp.proc.346.202.2018

Khim B-K, Tada R, Itaki T (2014) Different nature of glacial CaCO3 constituents between MIS 2 and MIS 12 in the East Sea/Japan Sea and its paleoceanographic implication. Quat Int 333:130-138

Kido Y, Minami I, Tada R, Fujine K, Irino T, Ikehara K, Chun JH (2007) Orbital-scale stratigraphy and high-resolution analysis of biogenic components and deep-water oxygenation conditions in the Japan Sea during the last 640 kyr. Palaeogeogr Palaeoclimatol Palaeoecol 247:32-49

Kimura J-I, Okada S, Nakayama K, Umeda K, Kusano T, Asahara Y, Tateno M, Danhara T (1999) Fission track ages of tephras from Daisen and Sambe volcanoes and their volcanological implications. Quat Res (Daiyonki-Kenkyu) 38:145-155 (in Japanese with English abstract)

Kubota Y, Kimoto K, Tada R, Oda H, Yokoyama Y, Matsuzaki H (2010) Variations of East Asian summer monsoon since the last deglaciation based on Mg/Ca and oxygen isotope of planktic foraminifera in the northern East China Sea. Paleoceanography 25:PA4205. https://doi.org/10.1029/2009PA001891

Kuroyanagi A, Kawahata H (2004) Vertical distribution of living planktonic foraminifera in the seas around Japan. Mar Micropaleontol 53:173-196

Lisiecki LE, Raymo ME (2005) A Pliocene-Pleistocene stack of 57 globally distributed benthic $\delta^{18} \mathrm{O}$ records. Paleoceanography 20:1-17

Locarnini RA, Mishonov AV, Antonov JI, Boyer TP, Garcia HE, Baranova OK, Zweng MM, Paver CR, Reagan JR, Johnson DR, Hamilton M, Seidov D (2013) World ocean atlas 2013, volume 1: temperature. U.S. Government Printing Office, Washington, D.C., p 40

Machida H (1999) The stratigraphy, chronology and distribution of distal markertephras in and around Japan. Glob Planet Chang 21:71-94

Machida H, Arai F (2003) Atlas of tephra in and around Japan: revised edition. Tokyo University Press, Tokyo (in Japanese), p 336

Matsui H, Tada R, Oba T (1998) Low-salinity isolation event in the Japan Sea in response to eustatic sea-level drop during LGM: reconstruction based on salinity-balance model. Quat Res (Daiyonki-Kenkyu) 37:221-233 (in Japanese with English abstract)

Matsumoto A (1996) K-Ar age determinations of young volcanic rocks-correction for initial 40Ar/36Ar ratios and its application. Chishitsu News 501: 12-17 (in Japanese)

Matsumoto A, Ui T (1997) K-Ar age of Ata pyroclastic flow deposit, southern Kyushu, Japan. Bull Volc Soc Japan 42:223-225 (in Japanese)

Matsumoto A, Uto K, Ono K, Watanabe K (1991) K-Ar age determinations for Aso volcanic rocks--concordance with volcanostratigraphy and application to pyroclastic flows. Program Abstr Volc Soc Japan 2:73 (in Japanese)

Matsuzaki KM, Suzuki N, Nishi H, Hayashi H, Gyawali BR, Takashima R, Ikehara M (2015) Early to Middle pleistocene paleoceanographic history of southern Japan based on radiolarian data from IODP Exp. 314/315 Sites C0001 and C0002. Mar Micropaleontol 118:17-33

Matsuzaki KM, Suzuki N, Nishi H, Takashima R, Kawate Y, Sakaii T (2014) Middle to Late pleistocene radiolarian biostratigraphy in the water-mixed region of the Kuroshio and Oyashio currents, northeastern margin of Japan (JAMSTEC Hole 902-(9001C). J Micropalaeontol 33:205-222

Matul A, Abelmann A, Tiedemann R, Kaiser A, Nürnberg D (2002) Late Quaternary polycystine radiolarian datum events in the Sea of Okhotsk. Geo-Mar Lett 22:25-32

Matul AG, Abelmann A, Nürnberg D, Tiedemann R (2009) Stratigraphy and major paleoenvironmental changes in the Sea of Okhotsk during the last million years inferred from radiolarian data. Oceanology 49:93-100

Mix AC, Bard E, Schneider R (2001) Environmental processes of the ice age: land, oceans, glaciers (EPILOG). Quat Sci Rev 20:627-657

Miyairi Y, (2007) New measure for determination Quaternary volcanic eruption age using accelerator mass spectrometric radiocarbon dating and red thermoluminescence dating Ph.D thesis, 168, The University of Tokyo

Miyairi Y, Yoshida K, Miyazaki Y, Matsuzaki H, Kaneoka I (2004) Improved ${ }^{14} \mathrm{C}$ dating of a tephra layer (AT tephra, Japan) using AMS on selected organic fractions. Nucl Instrum Methods Phys Res B 223-224:555-559
Miyoshi N, Fujiki T, Morita Y (1999) Palynology of a 250-m core from Lake Biwa: a 430,000-year record of glacial-interglacial vegetation change in Japan. Rev Palaeobot Palynol 104:267-283

Moriwaki H, Suzuki T, Murata M, Ikehara M, Machida H, Lowe DJ (2011) Sakurajima-Satsuma (Sz-S) and Noike-Yumugi (N-Ym) tephras: new tephrochronological marker beds for the last deglaciation, southern Kyushu, Japan. Quat Int 246:203-212

Motoyama I, Yamada Y, Hoshiba M, Itaki T (2016) Radiolarian assemblages in surface sediments of the Japan Sea. Paleontol Res 20:176-206

Muraoka H, (1991) Heat source systems in the Hakkoda geothermal field, Northeast Japan: Report Geological Survey of Japan 113-134 (in Japanese with English abstract)

Muza JP (1992) Calcareous nannofossil biostratigraphy from the Japan Sea, Sites 798 and 799: evidence for an oscillating Pleistocene oceanographic frontal boundary. Proc ODP Sci Results 127/128(Pt. 1):155-169

Nagahashi Y, Nakai S, Kikkawa K, Okudaira T, Yoshikawa S, Yoshida T (2015) Petrological properties of tephra beds based on the major and trace element composition of volcanic glass shards : a case study of the Osaka Group and the Takashima-oki drilling core sediments in Lake Biwa, Kinki district, Japan. Chikyu-Kagaku 69:205-222 (in Japanese with English abstract)

Nagahashi Y, Sato T, Takeshita Y, Tawara T, Kumon F (2007) Stratigraphy and chronology of widespread tephra beds intercalated in the TKN-2004 core sediment obtained from the Takano formation, Central Japan. Quat Res (Daiyonki-Kenkyu) 46:305-325 (in Japanese with English abstract)

Nagahashi Y, Yoshida T, Nakai S, Okudaira T (2003) Evaluation and correction of EDS results of the glass shards from some representative tephra by comparison with XRF analysis. Quat Res (Daiyonki-Kenkyu) 42:265-277 (in Japanese with English abstract)

Nagahashi Y, Yoshikawa S, Miyakawa C, Uchiyama T, Inouchi Y (2004) Stratigraphy and chronology of widespread tephra layers during the past 430 ky in the Kinki District and the Yatsugatake mountains: major element composition of the glass shards using EDS analysis. Quat Res (Daiyonki-Kenkyu) 43:15-35 (in Japanese with English abstract)

Nagatomo T, Shitaoka Y, Nishimura S (2005) Comparison of results between TL and OSL dating of the same tephras. Bull Nara Univ Educ 52:1-9 (in Japanese with English abstract)

Nakagawa M, Fujioka K, Furuta T, Koizumi S, (1994) Volcanic ash beds in the cores of the Leg.127 and 128 under Japan sea--volcanic ash correlations and estimation of active history of Quaternary volcanoes from major element compositions of volcanic glass shards. Chikyu Monthly 16 (in Japanese)

Nakajima T, Kikkawa K, Ikehara K, Katayama H, Kikawa E, Joshima M, Seto K (1996) Marine sediments and late Quaternary stratigraphy in the southeastern part of the Japan sea--concerning the timing of dark layer deposition. J Geol Soc Jpn 102:125-138 (in Japanese with English abstract)

Morley JJ. and Nigrini C. (1995) Miocene to Pleistocene Radiolarian Biostratigraphy of North Pacific Sites 881, 884, 885, 886, and 887. In Rea, D.K., Basov, I.A., Scholl, D.W. and Allan, J.F. (eds.) Proceedings of the Ocean Drilling Program Proc. ODP, Sci. Results, College Station TX (Ocean Drilling Program), 145:55-91 https://doi.org/10.2973/odp.proc.sr.145.107.1995

Oba T (1991) Aso-4 and Ata tephra from the viewpoint of oxygen isotope stratigraphy. Chikyu Mon 13:224-227 (in Japanese)

Oba T, Kato M, Kitazato H, Koizumi I, Omura A, Sakai T, Takayama T (1991) Paleoenvironmental changes in the Japan Sea during the last 85000 years. Paleoceanography 6:499-518

Okuno M (2002) Chronology of tephra layers in southern Kyushu, SW Japan, for the last 30,000 years. Quat Res (Daiyonki-Kenkyu) 41:225-236 (in Japanese with English abstract)

Okuno M, Nakamura T, Geshi N, Kimura K, Saito-Kokubu Y, Kobayashi T (2013) AMS radiocarbon dating of wood trunks in the pumiceous deposits of the Kikai-Akahoya eruption in Yakushima Island, SW Japan. Nucl Instru Meth Phys Res B 294:602-605

Pickering KT, Souter C, Oba T, Taira A, Schaaf M, Platzman E (1999) Glacioeustatic control on deep-marine clastic forearc sedimentation, Pliocenemid-Pleistocene (c. 1180-600 ka) Kazusa Group, SE Japan. J Geol Soc 156:125-136

Pouclet A, Scott S (1992) Volcanic ash layers in the Japan Sea: tephrochronology of Site 798 and 799. Proc ODP Sci Results 127/128(Pt. 2):791-803

Railsback LB, Gibbard PL, Head MJ, Voarintsoa NRG, Toucanne S (2015) An optimized scheme of lettered marine isotope substages for the last 1.0 million years, and the climatostratigraphic nature of isotope stages and substages. Quat Sci Rev 111:94-106 
Rohling EJ, Foster GL, Grant KM, Marino G, Roberts AP, Tamisiea ME, Williams F (2014) Sea-level and deep-sea-temperature variability over the past 5.3 million years. Nature 508:477-482

Satoguchi Y, Nagahashi Y (2012) Tephrostratigraphy of the Pliocene to Middle Pleistocene series in Honshu and Kyushu Islands, Japan. Island Arc 21:149-169

Shirai M (2001) Widespread tephra of the middle Pleistocene found in the eastern Japan Sea. Chikyu Mon 23:600-604 (in Japanese)

Shirai M, Tada R, Fujioka K (1997) Identification and chronostratigraphy of middle to upper Quaternary marker tephras occurring in the Anden coast based on comparison with ODP cores in the sea of Japan. Quat Res (Daiyonki-Kenkyu) 36:183-196 (in Japanese with English abstract)

Shitaoka Y, Fukuoka T, Hasegawa A, Kusano T, Nagatomo T (2009) Thermoluminescence dating of the pyroclastic deposits of the Sanbe Volcano. Bull Shimane Nat Mus Mt Sanbe (Sahimel) 7:15-24

Shitaoka Y, Moriwaki H, Akai F, Nakamura N, Miyoshi M, Yamamoto J (2016) Eruption age of Sakurajima-Satsuma tephra using thermoluminescence dating. Bull Geol Environ Sci 18:29-35

Siddall M, Rohling EJ, Almogi-Labin A, Hemleben C, Meischner D, Schmelzer I, Smeed DA (2003) Sea-level fluctuations during the last glacial cycle. Nature 423:853-858

Smith VC, Staff RA, Blockley SPE, Bronk Ramsey C, Nakagawa T, Mark DF, Takemura K, Danhara T (2013) Identification and correlation of visible tephras in the Lake Suigetsu SG06 sedimentary archive, Japan: chronostratigraphic markers for synchronising of east Asian/west Pacific palaeoclimatic records across the last $150 \mathrm{ka}$. Quat Sci Rev 67:121-137

Sparks RSJ, Walker GPL (1977) The significance of vitric-enriched air-fall ashes associated with crystal enriched ignimbrite. J Volcanol Geotherm Res 2:329-341

Tada R, lijima A (1983) Petrology and diagenetic changes of Neogene siliceous rocks in northern Japan. J Sediment Res 53:911-930

Tada R, Irino T, Koizumi I (1999) Land-ocean linkages over orbital and millennial timescales recorded in late Quaternary sediments of the Japan Sea. Paleoceanography 14:236-247

Tada R, Irino T, Ikehara K, Karasuda A, Sugisaki S, Xuan C, Sagawa T, Itaki T, Kubota Y, Lu S, Seki A, Murray RW, Alvarez-Zarikian C, Anderson WT Jr, Bassetti M-A, Brace BJ, Clemens SC, da Costa Gurgel MH, Dickens GR, Dunlea AG, Gallagher SJ, Giosan L, Henderson ACG, Holbourn AE, Kinsley CW, Lee GS, Lee KE, Lofi J, Lopes CICD, Pellitero MS, Peterson LC, Singh RK, Toucanne S, Wan S, Zheng $\mathrm{H}$, Ziegler $\mathrm{M}$, High-resolution and -precision correlation of dark and light layers in the Quaternary hemipelagic sediments of the Japan Sea recovered during IODP Expedition 346. Progress in Earth and Planetary Science [in press]. https://doi.org/10.1186/s40645-018-0167-8

Tada R, Koizumi l, Cramp A, Rahman A (1992) Correlation of dark and light layers, and the origin of their cyclicity in the Quaternary sediments from the Japan Sea. Proc ODP Sci Results 127/127(Pt. 1):577-601

Tada R, Murray R, Alvarez Zarikian C, Anderson W, Bassetti M-A, Brace B, Clemens S, da Costa Gurgel M, Dickens G, Dunlea A, Gallagher S, Giosan L, Henderson A, Holbourn A, Ikehara K, Irino T, Itaki T, Karasuda A, Kinsley C, Kubota Y, Lee G, Lee K, Lofi J, Lopes C, Peterson L, Saavedra-Pellitero M, Sagawa T, Singh R, Sugisaki S, Toucanne S, Wan S, Xuan C, Zheng H, Ziegler M, (2015a) Site U1427 In Tada, R., Murray, R.W., Alvarez Zarikian, C.A., and the Expedition 346 Scientists, Proc. IODP, 346, College Station, TX (Integrated Ocean Drilling Program), https://doi.org/10.2204/iodp.proc.346.108.2015

Tada R, Murray R, Alvarez Zarikian C, Anderson W, Bassetti M-A, Brace B, Clemens S, da Costa Gurgel M, Dickens G, Dunlea A, Gallagher S, Giosan L, Henderson A, Holbourn A, Ikehara K, Irino T, Itaki T, Karasuda A, Kinsley C, Kubota Y, Lee G, Lee K, Lofi J, Lopes C, Peterson L, Saavedra-Pellitero M, Sagawa T, Singh R, Sugisaki S, Toucanne S, Wan S, Xuan C, Zheng H, Ziegler M, (2015b) Site U1426 In Tada, R., Murray, R.W., Alvarez Zarikian, C.A., and the Expedition 346 Scientists, Proc. IODP, 346, College Station, TX (Integrated Ocean Drilling Program), https://doi.org/10.2204/iodp.proc.346.107.2015

Tada R, Murray R, Alvarez Zarikian C, Anderson W, Bassetti M-A, Brace B, Clemens S, da Costa Gurgel M, Dickens G, Dunlea A, Gallagher S, Giosan L, Henderson A, Holbourn A, Ikehara K, Irino T, Itaki T, Karasuda A, Kinsley C, Kubota Y, Lee G, Lee K, Lofi J, Lopes C, Peterson L, Saavedra-Pellitero M, Sagawa T, Singh R, Sugisaki S, Toucanne S, Wan S, Xuan C, Zheng H, Ziegler M, (2015c) Sites U1428 and U1429 In Tada, R., Murray, R.W., Alvarez Zarikian, C.A., and the Expedition 346 Scientists, Proc. IODP, 346, College Station, TX (Integrated Ocean Drilling Program), https://doi.org/10.2204/iodp.proc.346.109.2015

Tada R, Murray R, Alvarez Zarikian C, Anderson W, Bassetti M-A, Brace B, Clemens S, da Costa Gurgel M, Dickens G, Dunlea A, Gallagher S, Giosan L, Henderson A,
Holbourn A, Ikehara K, Irino T, Itaki T, Karasuda A, Kinsley C, Kubota Y, Lee G, Lee K, Lofi J, Lopes C, Peterson L, Saavedra-Pellitero M, Sagawa T, Singh R, Sugisaki S, Toucanne S, Wan S, Xuan C, Zheng H, Ziegler M, (2015d) Methods, In Tada, R., Murray, R.W., Alvarez Zarikian, C.A., and the Expedition 346 Scientists, Proc. IODP, 346, College Station, TX (Integrated Ocean Drilling Program), https://doi.org/10. 2204/iodp.proc.346.102.2015

Tamura I, Yamazaki H (2010) Significance of the remarkable unconformity in the Plio-Pleistocene of the Japanese Islands. Quat Int 219:45-54

Torii M, Yoshikawa S, Itihara M (1974) Paleomagnetism in the water-laid volcanic ash layers in the Osaka Group, Sennan and Senpoku hills, southwest Japan. Rock Magn Paleogeophysics 2:34-37

Tsuji T, Miyata Y, Okada M, Mita I, Nakagawa H, Sato Y, Nakamizu M (2005) Highresolution chronology of the lower Pleistocene Otadai and Umegase Formations of the Kazusa Group, Boso Peninsula, central JapanChronostratigraphy of the JNOC TR-3 cores based on oxygen isotope, magnetostratigraphy and calcareous nannofossil. J Geol Soc Jpn 111:1-20 (in Japanese with English abstract)

Uto K, Suto S, (1985) K-Ar age determination of volcanic rocks from the Hohi geothermal area, Kyushu, Japan. Geological Survey of Japan, pp. 67-83 (in Japanese with English abstract)

Yokoyama Y, Kido Y, Tada R, Minami I, Finkel RC, Matsuzaki H (2007) Japan Sea oxygen isotope stratigraphy and global sea-level changes for the last 50,000 years recorded in sediment cores from the Oki Ridge. Palaeogeogr Palaeoclimatol Palaeoecol 247:5-17

Yokoyama Y, Lambeck K, De Deckker P, Johnston P, Fifield LK (2000) Timing of the Last Glacial Maximum from observed sea-level minima. Nature 406:713-716

Yoshikawa S, Inouchi Y (1993) Middle Pleistocene to Holocene explosive volcanism revealed by ashes of the Takashima-oki core samples from Lake Biwa, central Japan. Chikyu-Kagaku 47:97-109 (in Japanese with English abstract)

Yoshikawa S, Kuwae M (2001) High precision tephrochronology for the past 400 ky using Lake Biwa sediment. Chikyu Mon 23:594-599 (in Japanese)

Young J, Geisen M, Cros L, Kleijne A, Sprengel C, Probert I, Ostergaard J (2003) A guide to extant coccolithophore taxonomy. J Nannoplankton Res Spec Issue 1:1-125

\section{Submit your manuscript to a SpringerOpen ${ }^{\mathcal{O}}$ journal and benefit from:}

- Convenient online submission

- Rigorous peer review

- Open access: articles freely available online

- High visibility within the field

- Retaining the copyright to your article

Submit your next manuscript at $>$ springeropen.com 